諸生

單色 係文種肪方

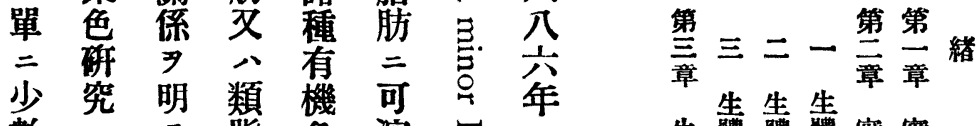

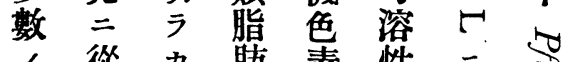

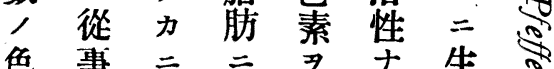

素弪七可用ル體々

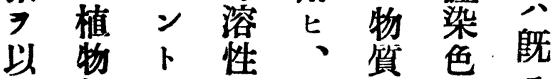

細 企

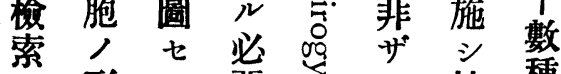

3 形》要过 $v$ 植種

行態。ナ學公細色

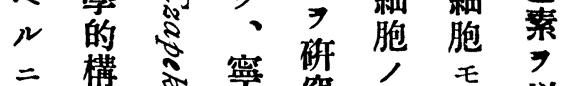

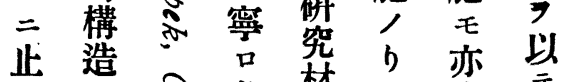

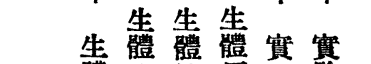

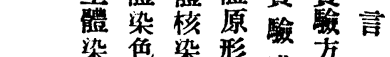

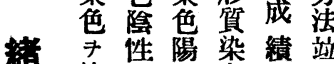

复性陽染績端

マ八尺色材ほ素料

施宁烧色

七ルナ陽

ル色儿植角

物粢儿料

供

稩種色

胞類種

哲程

植

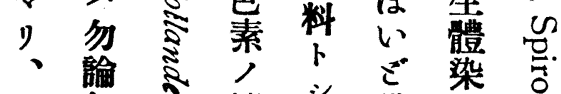

色細 今擴 シ 膜色染

素胞》散植买可主

性分嵗令能物過苚能

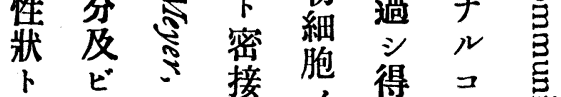

該其え接分得

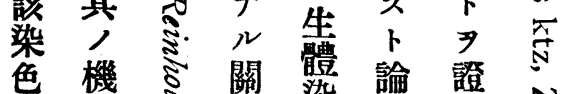

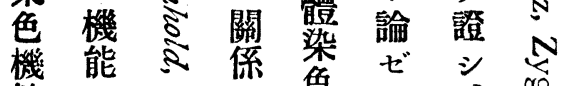

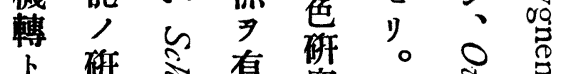

, 䂠替替有究然

關

係從等述從二事二道志

閪七諸 以 シ 九性 声

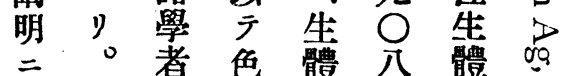

文概第第

目

物

細

万然相急體 八體梁

ルレ次色二色总.

二ト デ生陽至色

至モ 植 體 性 り 素 す 献括留物生生粗

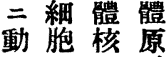

物, 染形

細生色貿

胞體三染

染就色

細機就

番

生 色

䌡萦,

染 理

花

, 學

毕的性

次

生

ザ是物染染細色脂

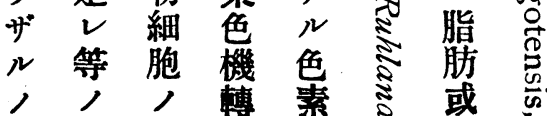

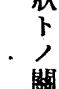

郎 廣 
サ 7 應

其

寞

く 中 染 ト

岕. ナ 選

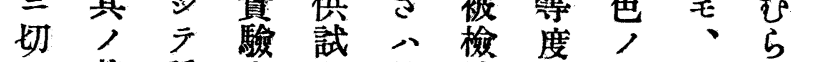

り基種方色植植二制原さ故ル

于底々 法素物物發別形き点二, 物

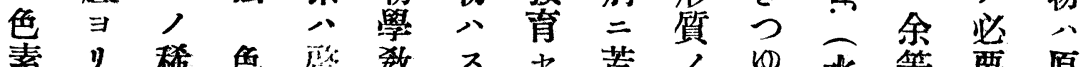

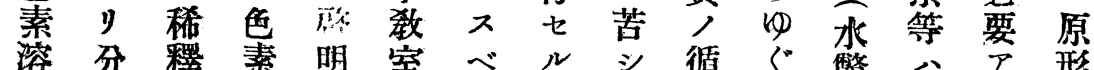

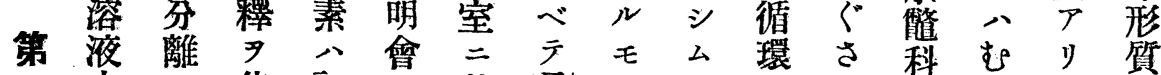

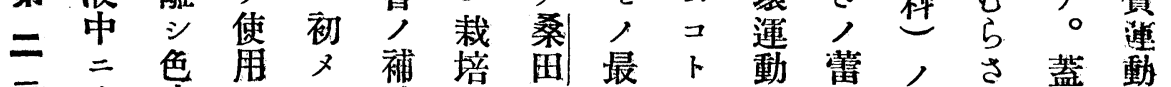

豆入素 七

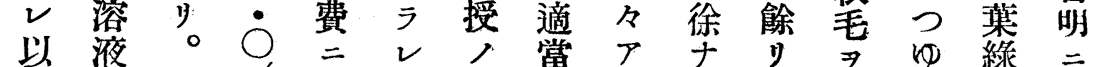

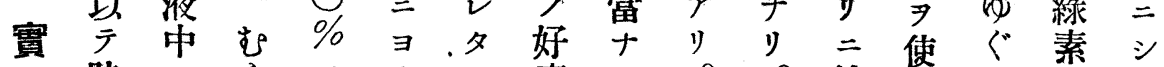

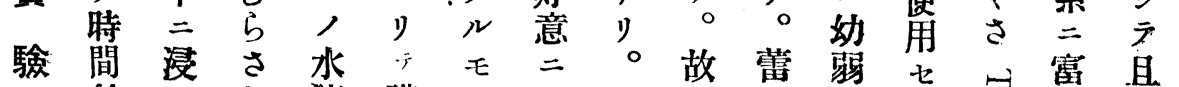

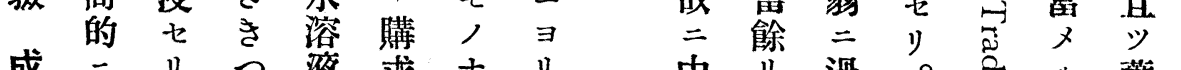

成二リつ夜求ナ

績其を゙

染ち さ シ v

色加二其 夕

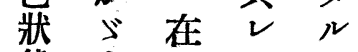
態みリ

$\exists=$ テノ

觀 在 八更 =

察 其 $三$ テ

七テノ千殆

り、中倍 次

其 度 等

其荎百

中成百種

等 熟 萬

度七倍 選

長䈏 釋 擇

サ ヨ 等り

モ取色

尹 雄種

選 梁 類

ビ刃及

根 露 ビ

7. 出 檢

適 泼

當、花間

長 統 二

$\varepsilon$ 等 $=$ 安

ち 熟

加成 $シ$ ₹

方熟 テ開

小方花核

巨比分

棕

池

二

テ

探

取

惠

セ

亏

2

シ

モ

ち, テ

加其 且

=

テ み細 其

む根液存

ら笔在

a $E$ 色 明

き同名白

樣带
次葉

モ 綠

品

其 含 材

分有 料

染

官色为

上狀 事

態㒖

䲧人少

卧检二

草 查 テ

科二核

犁了,

雄夕存

㥯

毛其 容

所 二

蓝 組 認

$=$ \%

を審 得

ち 二

加水

ॐ゙ル、

み事か

困 如

難手

官材

号料
關胞 喊

係蓝厂

明細。

力 畨 故

$=\gamma=$

七生余

ン 體 等

第卜染 八

シ 色 清

本 對 教

研 三 授

究 如及

實 二 们 ビ

駼着大植

方手心物

法七關學

前り係 教

供○ル室

ヤ田

3 教

此授

較 指

研・道

究不

且 植

产 物

植 細

物 胞

細人

胞 生

人 體

生 染

體 色

染 研

色 究

槭 三

轉 從

: 事

色 シ

素 以

今

諸 高

性 等

狀 動

濒 


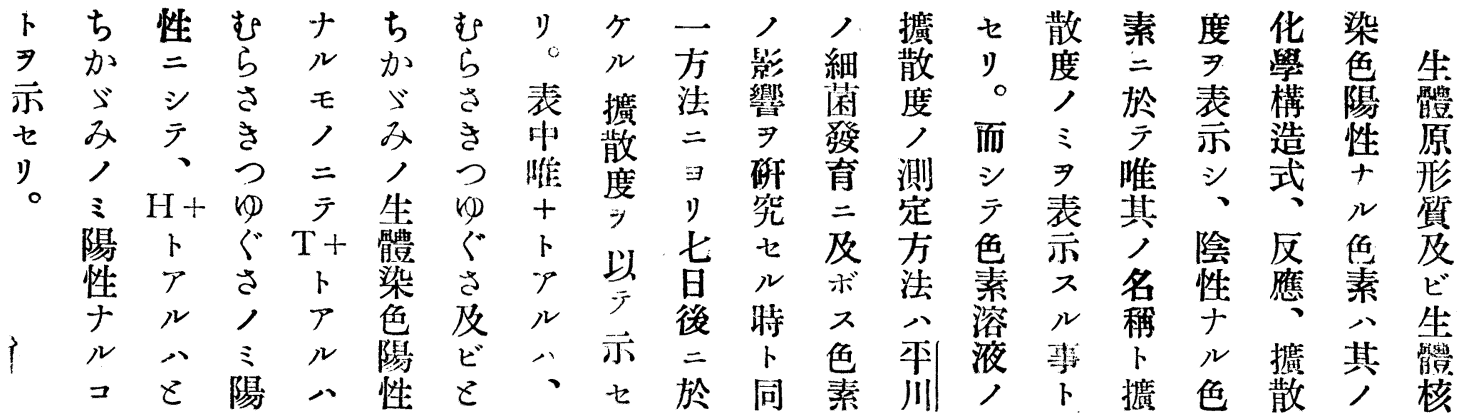
第一表生體原形質染色隄性ナル色素ノ種類 一酸情色素基性素

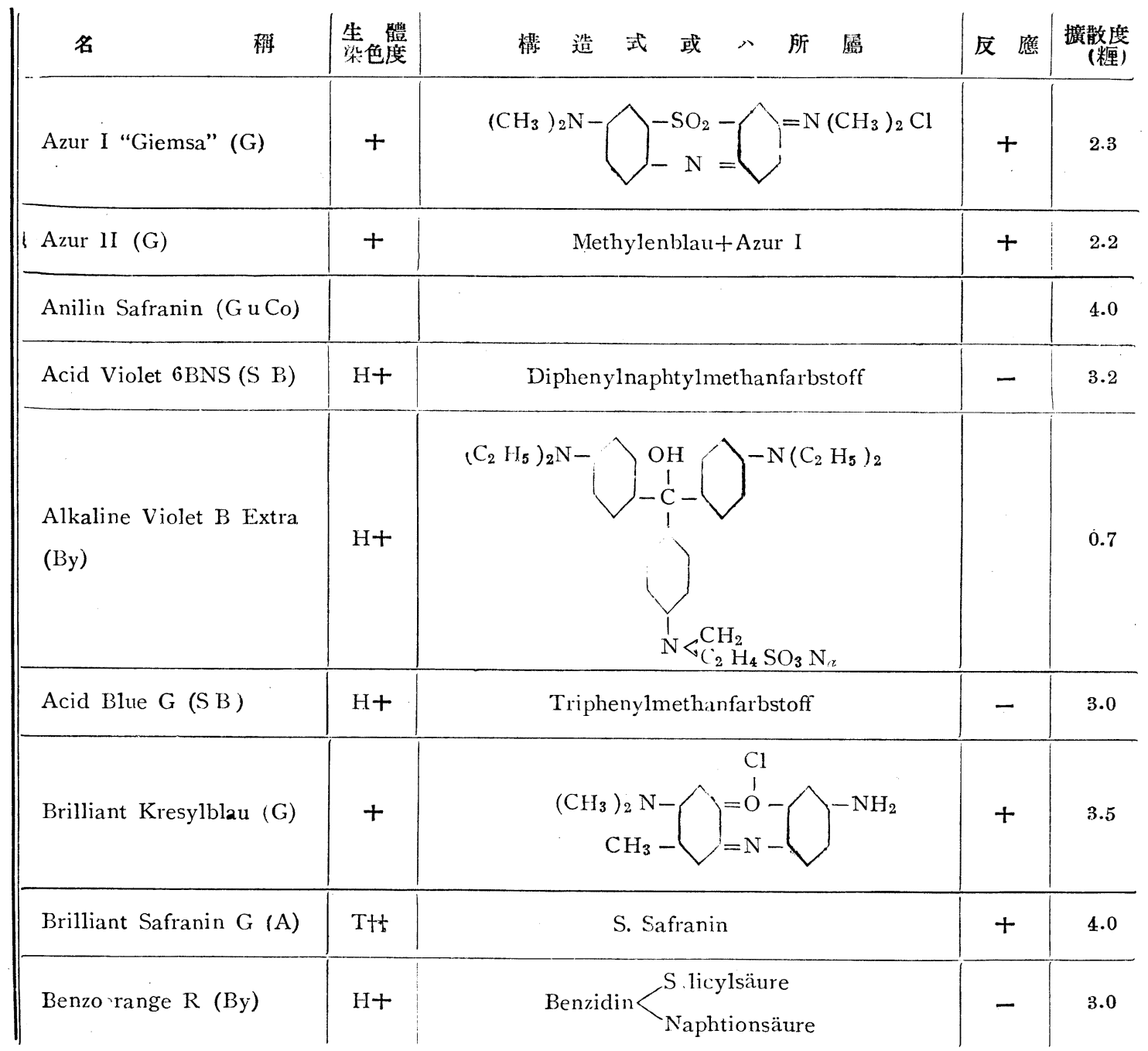


(561)

述郎一平林竹 - 度平

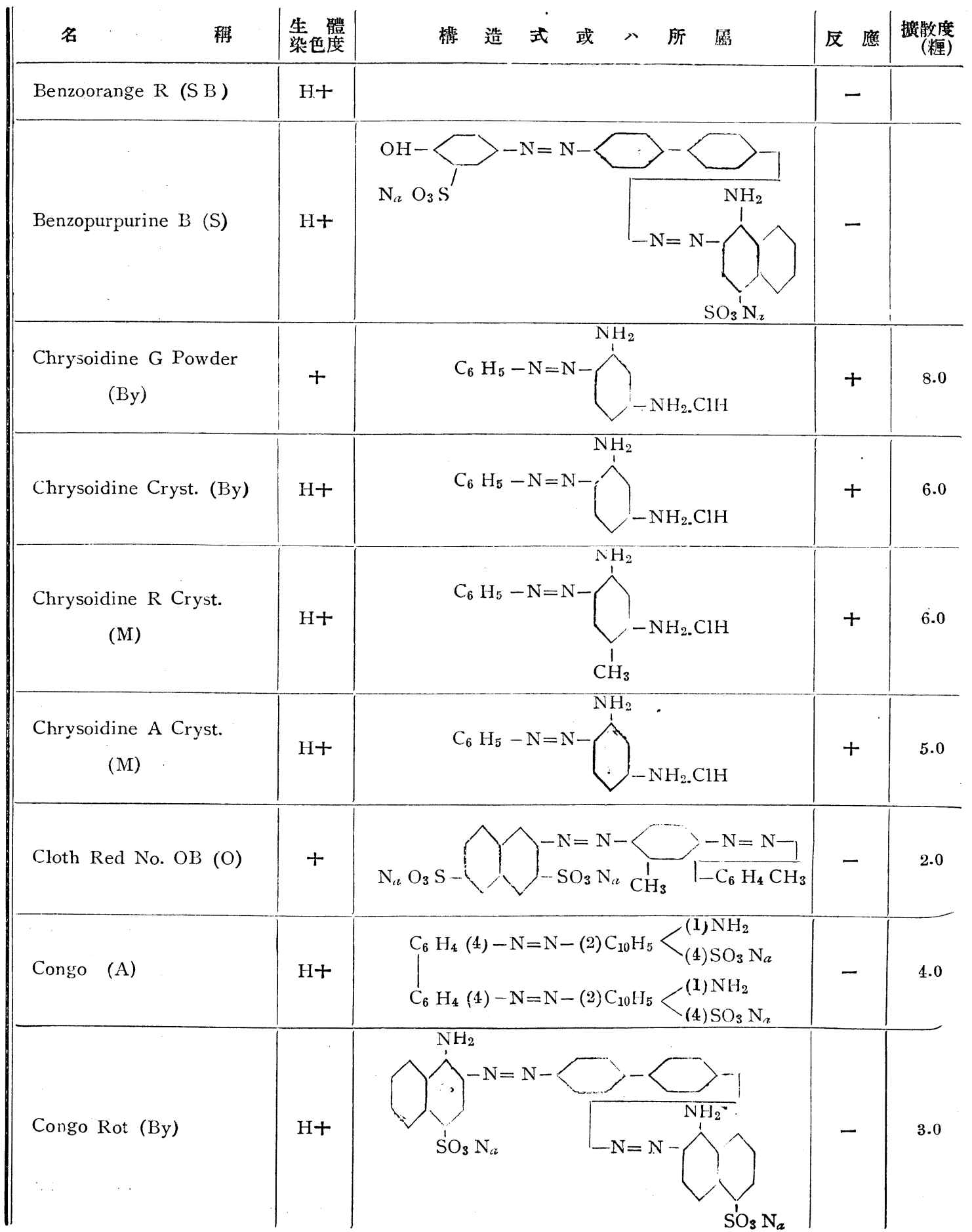




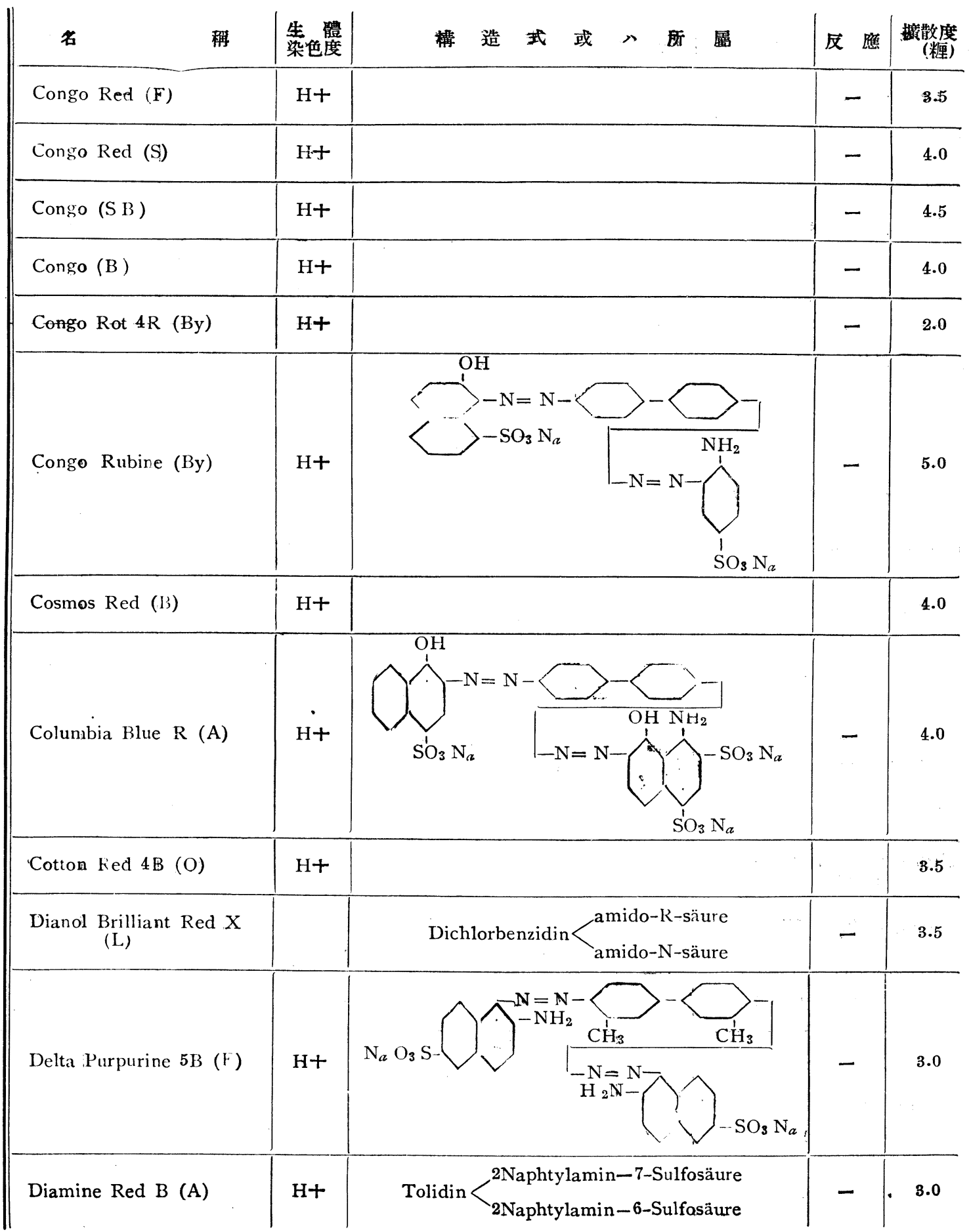




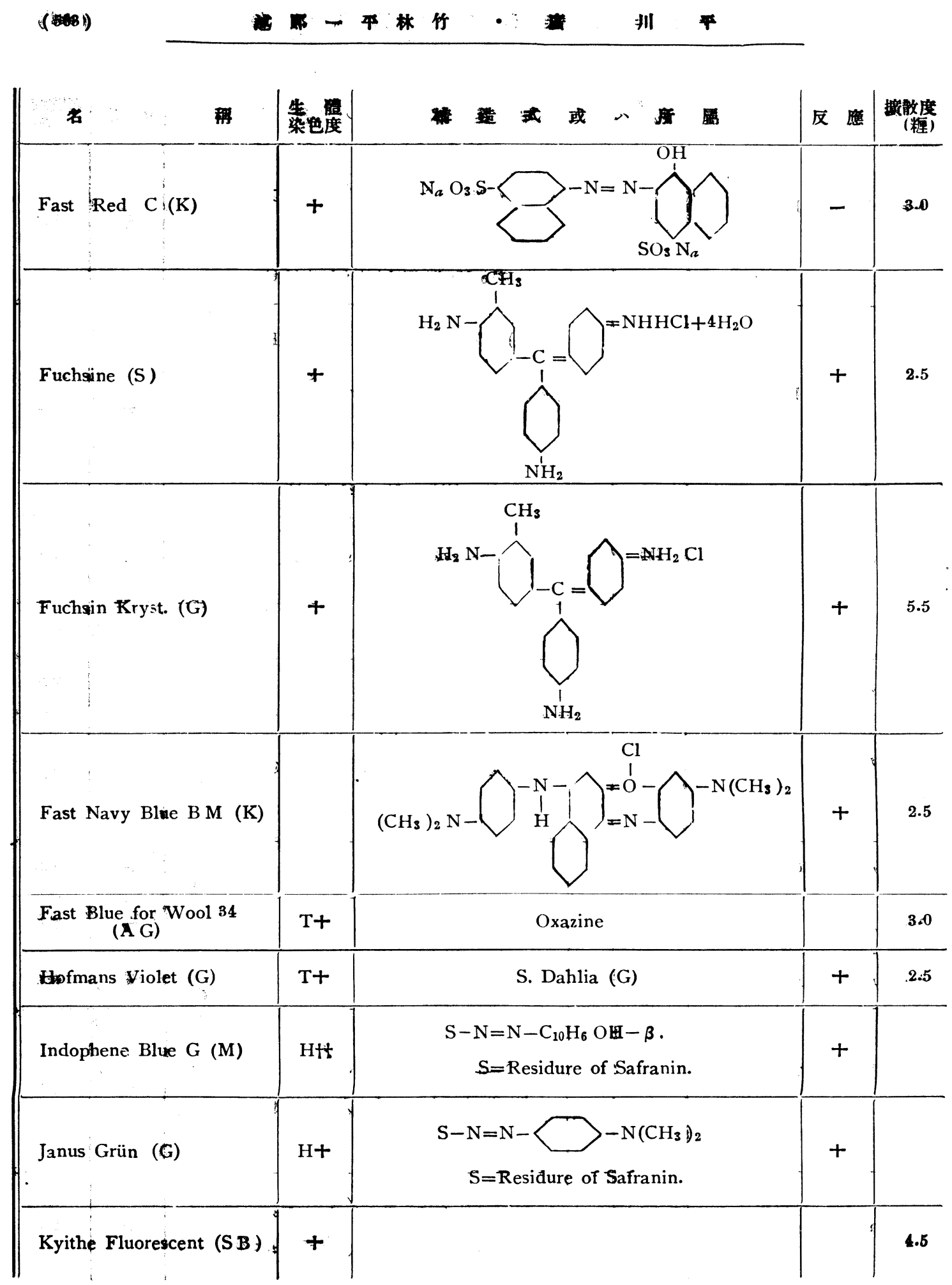




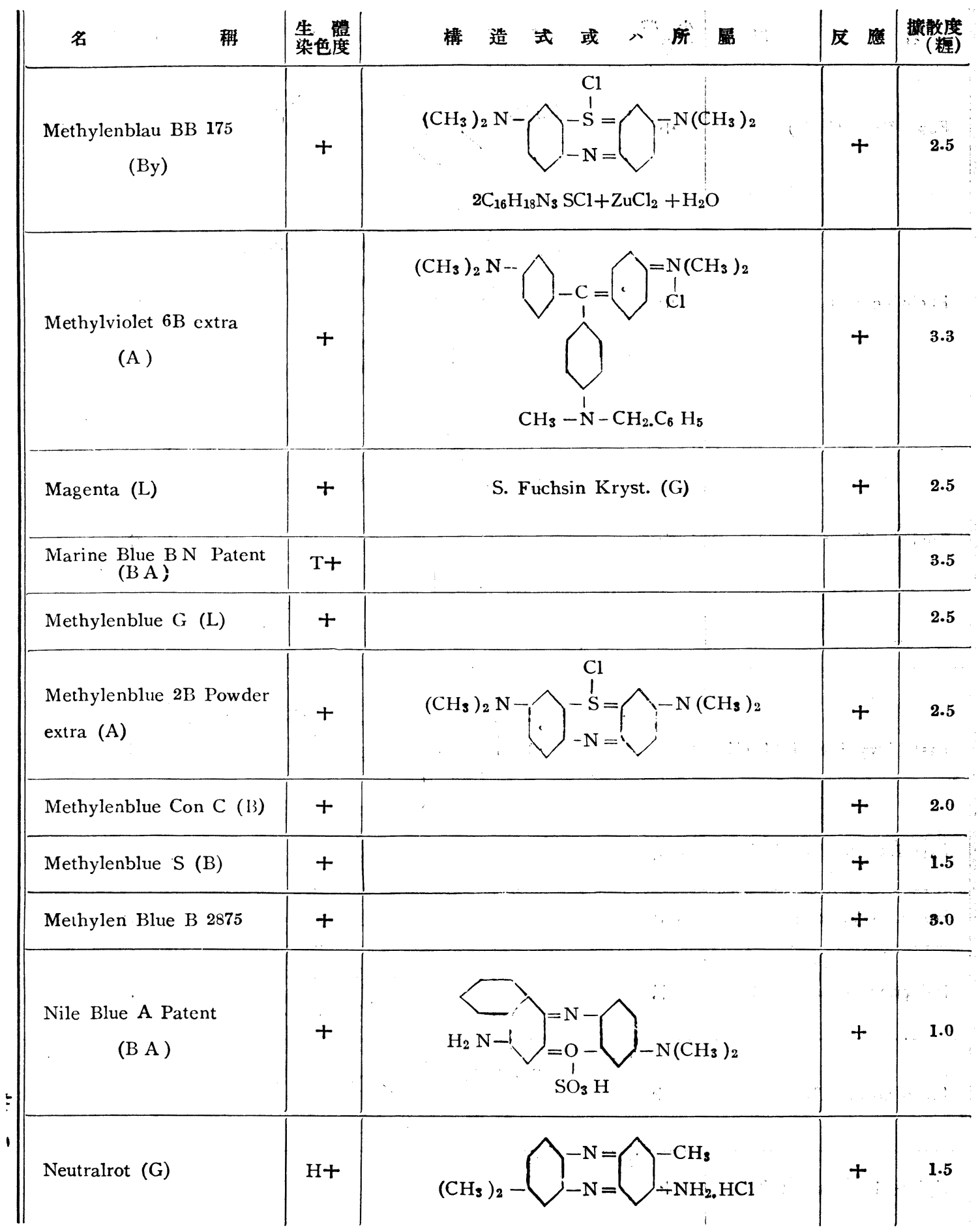


$(565)$

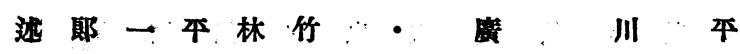

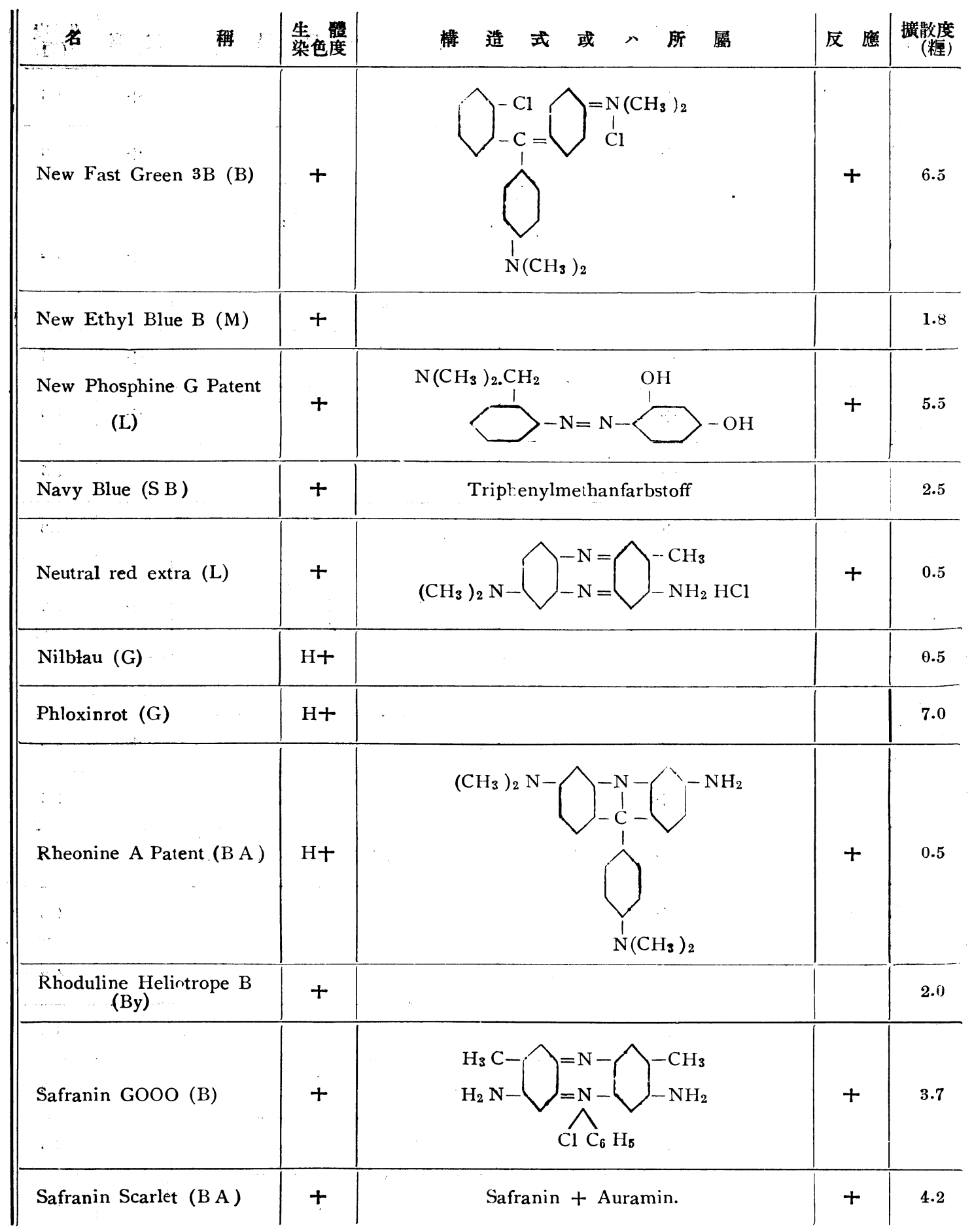




\begin{tabular}{|c|c|c|c|c|}
\hline 名 & 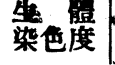 & 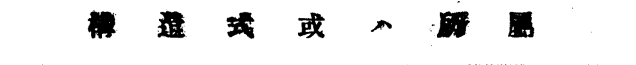 & 反 碓 & 糧) \\
\hline Safranin No. 4420 (M) & + & & + & 4.5 \\
\hline Safranïn $04(M)$ & + & & + & 4.0 \\
\hline Safranin $\mathrm{T}$ extra & + & $-\mathrm{NH}_{2 \xi}$ & + & 3.0 \\
\hline Safranin $\mathrm{Kg}$ (M) & + & & + & 3.5 \\
\hline Safranin GOOO (M) & + & & + & 4.0 \\
\hline Solid blve $2 \mathrm{~B}(\mathrm{~S})$ & + & . & 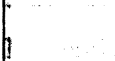 & 1.5 \\
\hline Tannin Blue RNE (B A) & + & & & 3.0 \\
\hline Toluidinblau (G) & + & $=\mathrm{NH}_{2} \mathrm{Cl}$ & + & 1.3 \\
\hline Tannin-Violet $2 \mathrm{~B} \cdot(\mathrm{B} \cdot \mathrm{A})$. & + & & & \\
\hline $\begin{array}{c}\text { Tannin Orange RE } \\
\text { (B A) }\end{array}$ & + & baviseher Azefarbstoff? & + & 20 \\
\hline$\underset{(B \mathrm{~A})}{\text { Tannin Orange } \mathrm{GE}}$ & $T+$ & & & 1.5 \\
\hline Türkir Blan BB (By) & it & Triphenylmethanfarbstoff + Diamidderivate & 3 & 5 \\
\hline Tannin Red BE (B A) & $T+$ & & & 4.0 \\
\hline Tannil Pink EB (B A) & $\mathrm{T}+$ & & & 42 \\
\hline Tannin BIue $\mathrm{R}$ & + & & & 2.0 \\
\hline Tannin Blue B:F & + & & 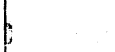 & 1.0 \\
\hline Tiefblau G (By) & + & & & 2.0 \\
\hline Tannin Reut GE (B A) & + & & & s.t. \\
\hline
\end{tabular}


(567)

速郎一平林行。度平

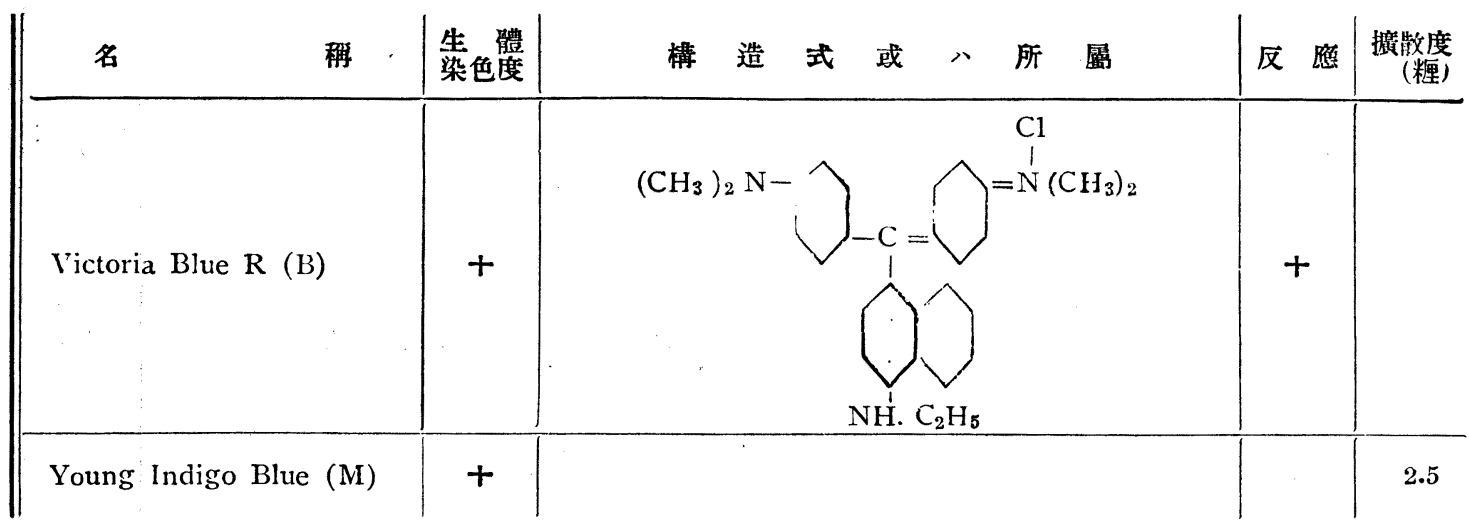

第 二 表 生體核染色陽性ナル色素ノ種類

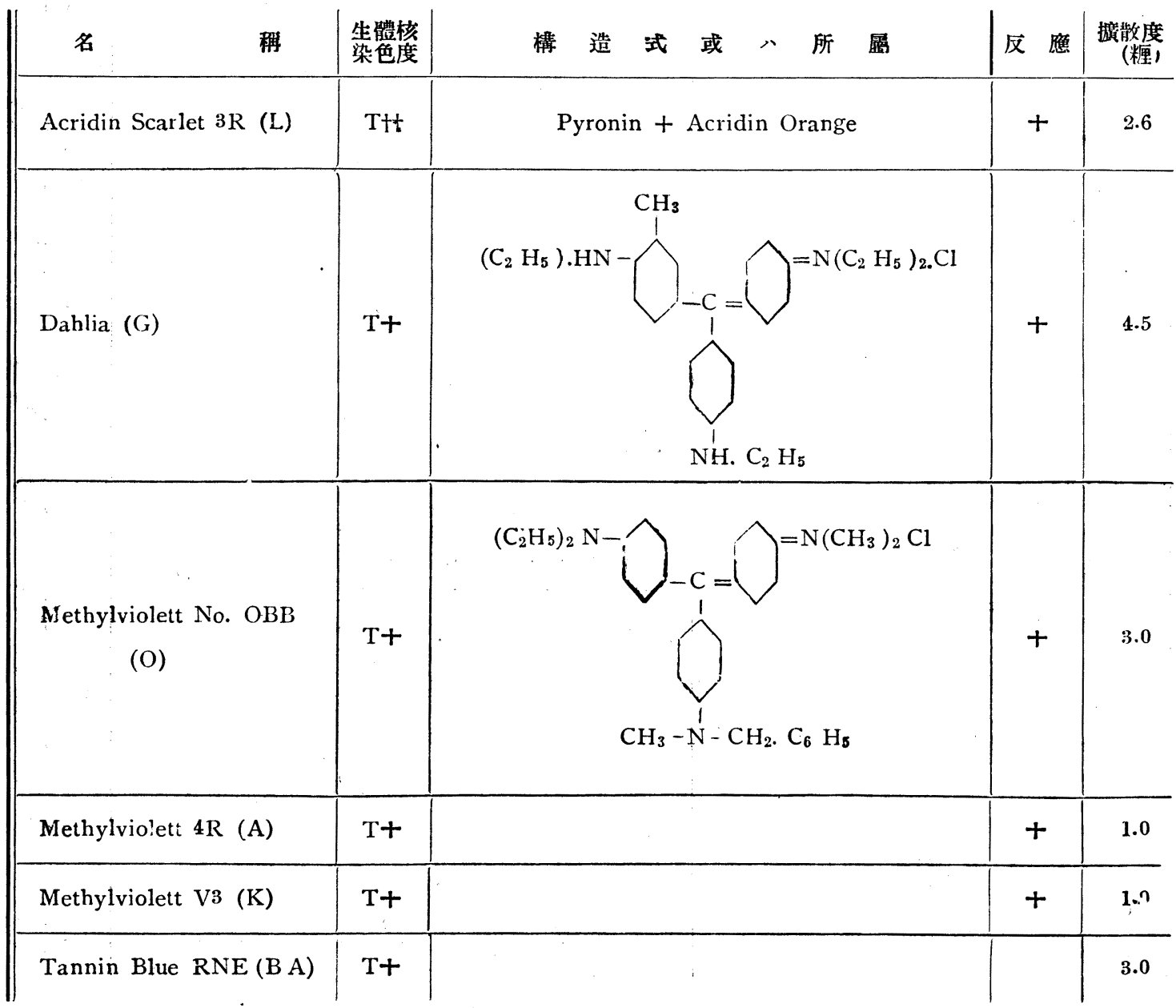




\section{第三表 生體染色陰性テル色素ノ種類}

\begin{tabular}{|c|c|c|c|}
\hline 秷 & $\begin{array}{r}\text { 摭教度 } \\
\text { (粴) }\end{array}$ & 和 & $\begin{array}{c}\text { 捇警度 } \\
\text { (糎) }\end{array}$ \\
\hline Acid Anthraceneked $G(B y)$ & 4.0 & Fast Acid Violet A $2 R \quad(M)$ & 6.0 \\
\hline Acid Violet $6 \mathrm{BN}$ & 4.0 & Fast Navy Blue RM (K) & 0.7 \\
\hline Acid Violet $4 \mathrm{~B}$ extra (By) & 4.5 & Formylviolet S $4 \mathrm{~B}$ & 4.5 \\
\hline Acid Rhodamine RRR & 5.5 & Fast Cotton Red extra (B A) & 3.7 \\
\hline Azo mernio Blue $(G)$ & 4.0 & Indigocarmin & 5.0 \\
\hline Azo Fuchsine 6B (By) & 5.0 & Indophene Blue $(\mathrm{M})$ & 0 \\
\hline Azo Blue (By) & 4.5 & Janus Blue $\mathrm{R}(\mathrm{M})$ & 0 \\
\hline Patent Acid Violet $63 \mathrm{~N}$ & 4.5 & Janus Green B (M) & 5.3 \\
\hline Alkali Blue & 1.0 & Janus Blue G $(\mathrm{M})$ & 1.5 \\
\hline Acid Blue R (S B) & 5.5 & Kanne P Fluo: escent (S B) & 6.5 \\
\hline Alizarine Cyanine WRB Powder (By) & 3.0 & Leather Yellow P (F P) & 2.0 \\
\hline Alkali Blue B (A) & 1.3 & Leather Yellow R (F P) & 1.0 \\
\hline Alkali Blue $6 \mathrm{~B}(\mathrm{~A})$ & 1.0 & Methylviolett $3 \mathrm{R}(\mathrm{K})$ & 1.0 \\
\hline Alizarine Cyanine WRR Powder (By) & 35 & Methyl Green Cryst. (A G) & 5.5 \\
\hline Alizarine Cyanine $3 \mathrm{R}$ Powder (By) & 0.9 & Malachite Green (SB) & 6.0 \\
\hline Azo Marine Blue R $(\mathrm{O})$ & 3.5 & Mandarine Orange G(By) & 7.5 \\
\hline Azo Navy Blue $(\mathrm{O})$ & 2.5 & Methylen Blue R (S B) & 6.5 \\
\hline Acid Blue $\mathrm{R}$ (S.B) & - & Metaphenylene Blue B (L) & 4.0 \\
\hline Renzopurpurine $4 \mathrm{~B}(\mathrm{O})$ & 1.8 & Muscat in $(\mathrm{G})$ & 1.0 \\
\hline Brilliant Grün (G) & 6.5 & Navy Biı e (S B) & 3.6 \\
\hline Benzo Azirine 3R & 3.5 & Neu Echt Blau (By) & 2.0 \\
\hline Brilliant Azirine 5R (By) & 6.0 & Neu Blau R (By) & 1.5 \\
\hline Benzo Schwarz Blau 5G (By) & 2.0 & Night Blue (S) & 0 \\
\hline Bordeaux B extra & 3.0 & Neu Magenta & $3 \cdot 5$ \\
\hline Brilliant Blue $(\mathrm{G})$ & 1.0 & Naphthamine Yellow 3G (K) & 3.5 \\
\hline Brilliant Blue G (S) & - & Neugrün Kryst (By) & 5.5 \\
\hline Chrysoidine R (L) & 7.0 & Primuline $(\mathrm{K})$ & 2.5 \\
\hline Cochinil & 3.5 & Fhosphine $(\mathrm{O})$ & 4.0 \\
\hline Crystal Violet (S B) & 3.0 & Fhloxine Extra $(\mathrm{M})$ & 6.5 \\
\hline Chinolingelb (By) & 6.3 & Tatent Indon Blue BB Powder & 0 \\
\hline Cyanine $(\mathrm{G})$ & 8.0 & Phloxine $\mathrm{P}(\mathrm{B} \mathrm{A})$ & - \\
\hline Cioth Red (B A) & 3.7 & Phenylamine Black C (By) & 3.0 \\
\hline Diamin Catechin (C) & 0.7 & Phloxine Cryst (M) & 6.5 \\
\hline Dianol Brown 3R (M) & 0.7 & Rhoduline Violett (By) & 6.5 \\
\hline Dark Blue B 838 (B A) & 4.5 & Rhodamine $3 \mathrm{G}$ (B) & 6.3 \\
\hline Diazine Green $(\mathrm{K})$ & 2.0 & Resorcine Brown (A G) & 5.5 \\
\hline Diamont F uchsin Cryst (By) & 5.0 & Soluble Blte (S_B) & 2.5 \\
\hline Diamond Green B (B A) & 6.0 & Thiocarmin $\mathrm{R}(\mathrm{B} \mathrm{A})$ & 5.5 \\
\hline Ethyl Violet $(\mathrm{SC})$ & 0.5 & Tartrazin (B) & $7.3^{-}$ \\
\hline Ecsine H S (S B) & 7.0 & Trypanblau $(G)$ & 6.0 \\
\hline Eosine Scar'et $B(B)$ & 0.5 & Trypanrot $(\mathrm{G})$ & 5.0 \\
\hline Erythrosine (S B) & 6.5 & Toluylene Brown G $(\mathrm{O})$ & 4.8 \\
\hline Eosine GGG (i) & 6.0 & Thionin pur (G) & 1.4 \\
\hline Fast Blue No, $20(F)$ & 4.5 & Tolidinblau (G) & 6.0 \\
\hline
\end{tabular}




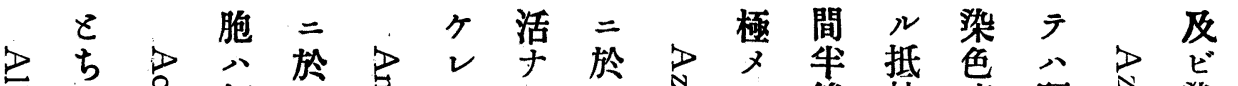

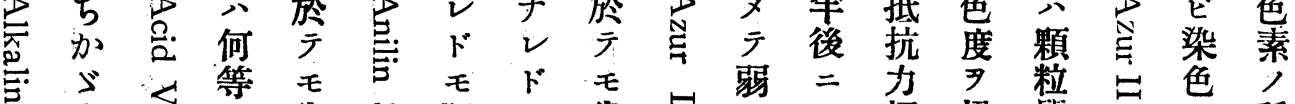
志 み゙

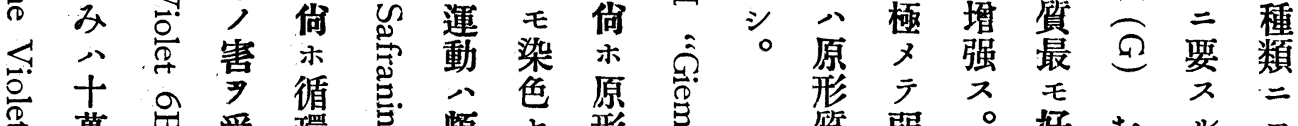

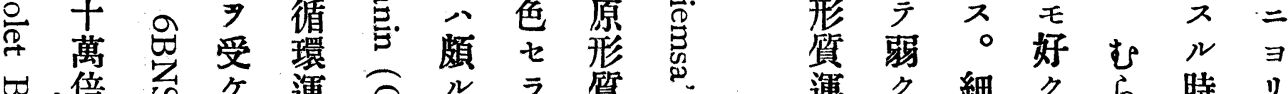

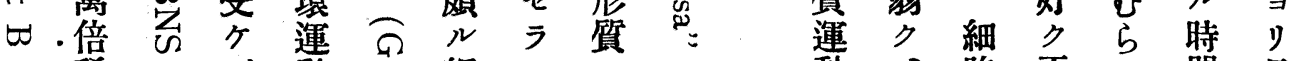

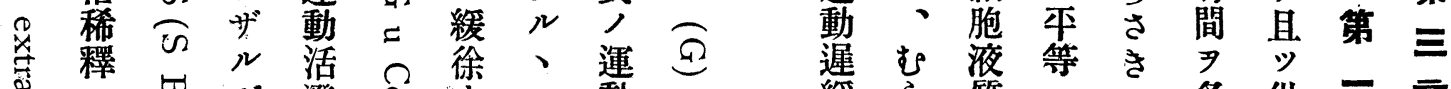
Ð 三 氖 三む 如 ナ 節

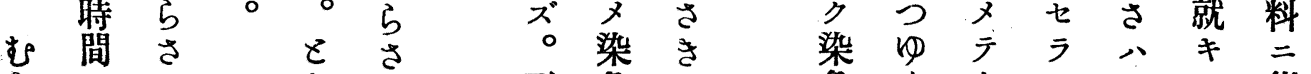

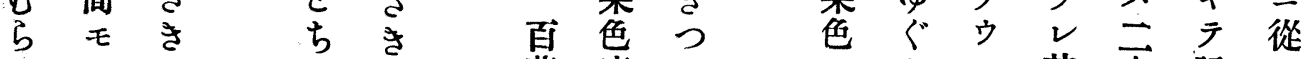

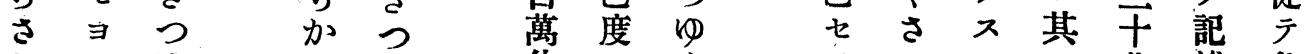
きクゆかゆ倍モだ

生ぐ $く$ 稀亦さ

ゆ存さ

ぐ シ 八 對 八

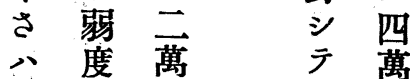

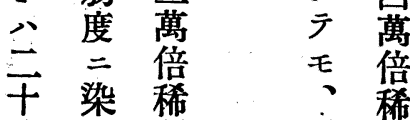

䆁 㙕 二

二强 在

於元少

四色 䆁

香 稀

時 七 萬

間 ラテ 倍 テ

後云。稀 五

於：四 䆁 間

省 装於後

佾 間 天=

木 二 - 可

不至時

染少間り

性 竟牛当

チ 毫

ド染染

、色 生七

$飞$ 七 體 う

テ $○$ テ

드

ラ 二クノ萬逝色

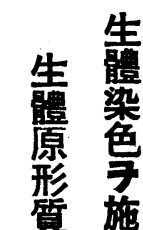

時 加萬

ル於、中倍 シ 素

○ケ染二稀 染 溶

二ル色抱釋色液

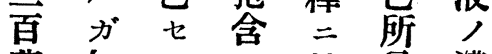

萬如 ラセ於見濃

染七

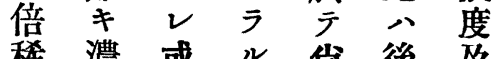

間 ぶ 倍

稀 濃或ル份後及

後 み稀

䆁 度 、、木二ビ

二 二㱠 顆 二一染

二 二 釋

於在年粒干括色

弱 テ

テリドモ 四 シ 時

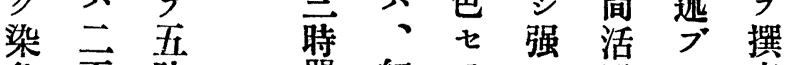

色 百 時

七萬 間

ラ 倍 後

ᄂ 稀 二

、睡 弱

豆 於 染

間細ラサ潑べ定

th

㤎

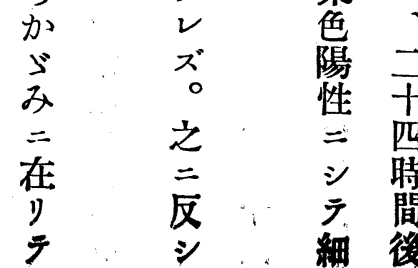

間 テ色

後 、七

二 原

後胞 $v=\doteq シ$

八形 v

卜 八ザ 染 循

踓皆ル色 環

モ死ナ七運

ヨ滅门。動

色 植

就 物

細

染質 ?

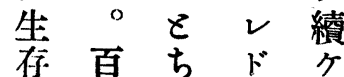

色度迴 干

ス萬加

卜倍 後染

胞

二轉四

雖稀 み二色

變 運 時

其 䆁色至賞

化動 間

於素厅初

染 テ = 漸 =

色度㭙

=

色

所

ナ 微 


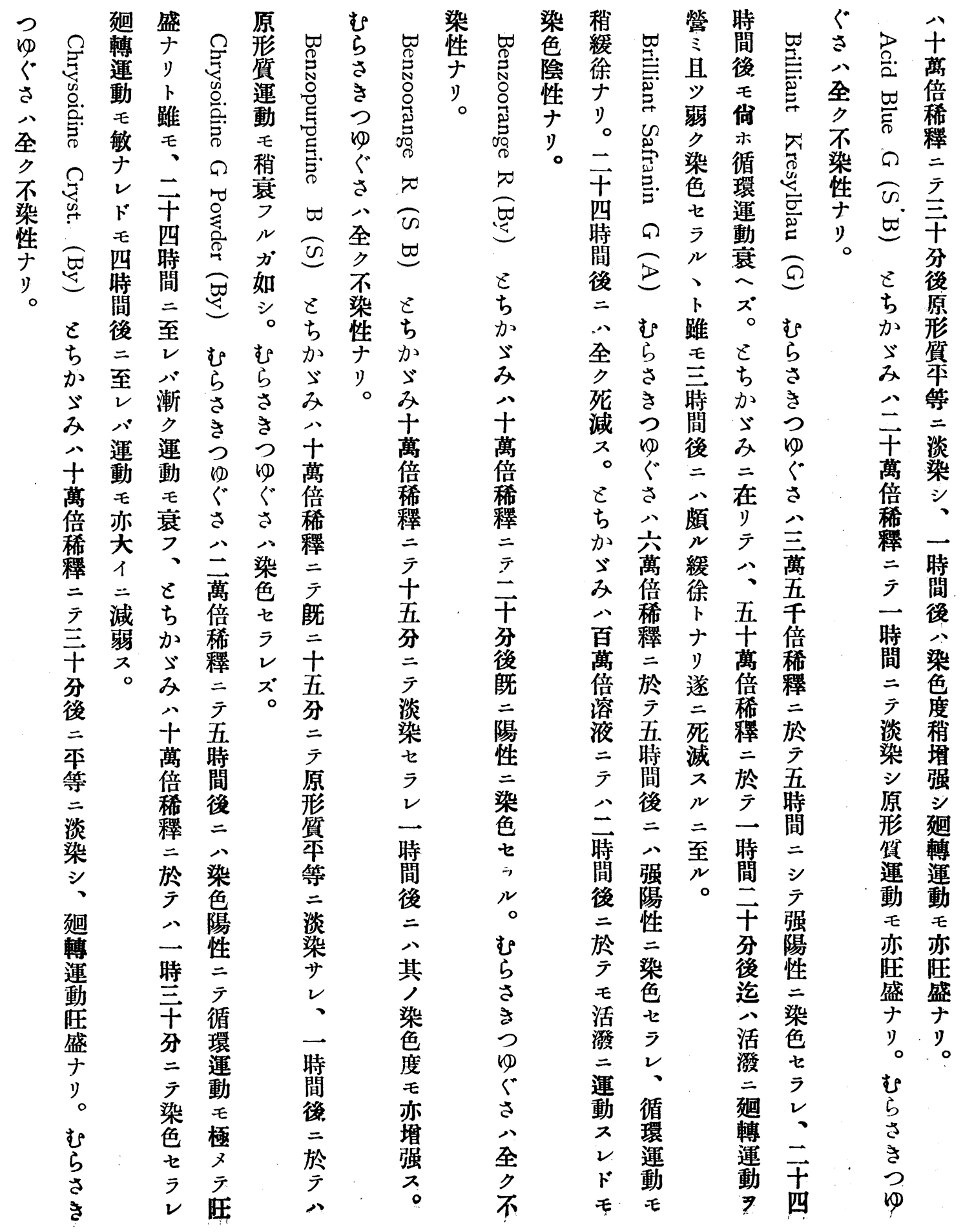




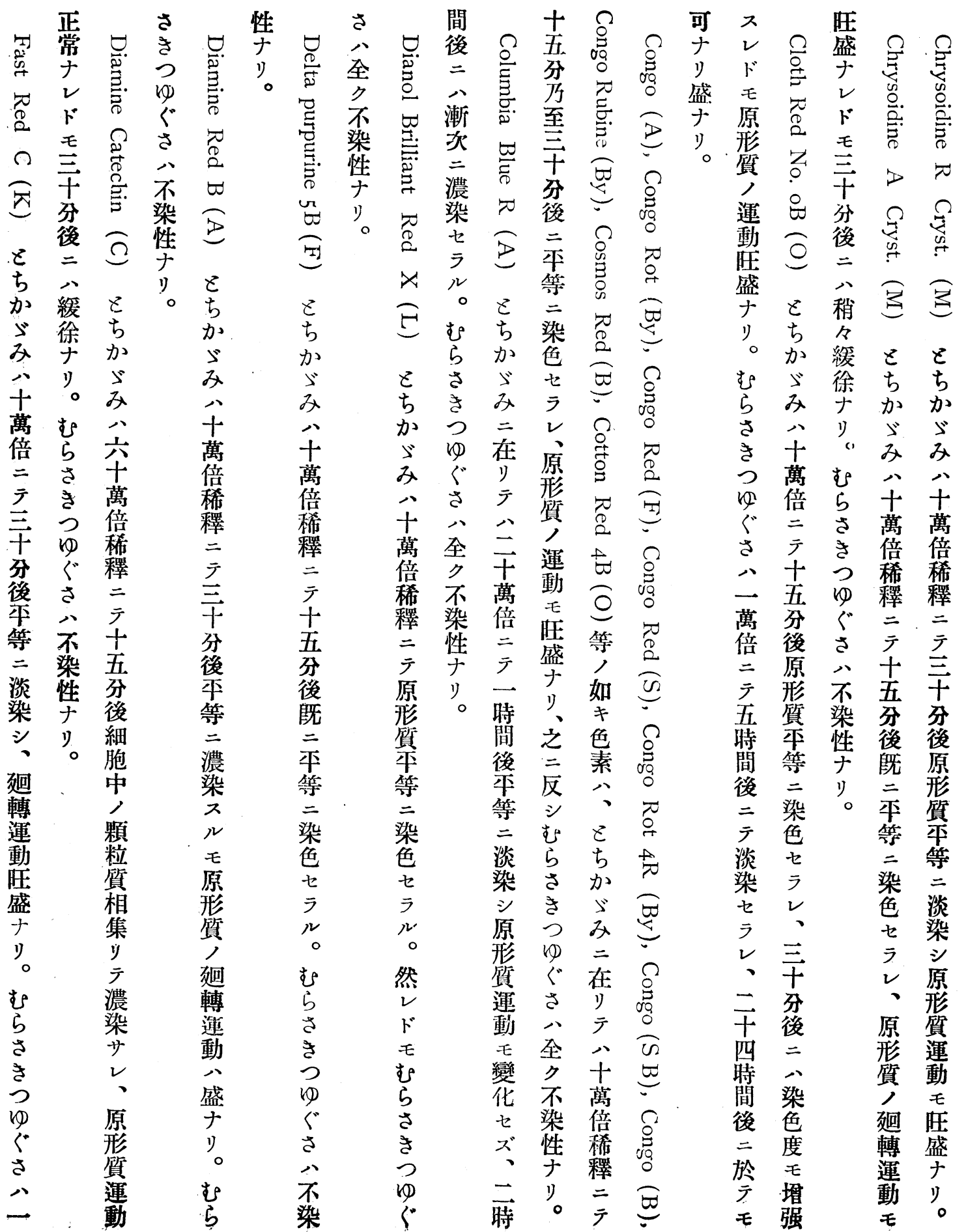




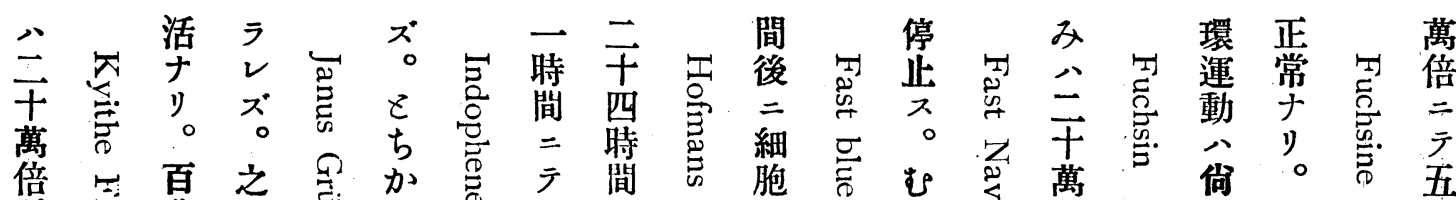

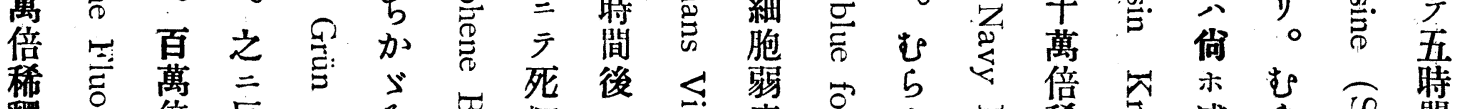

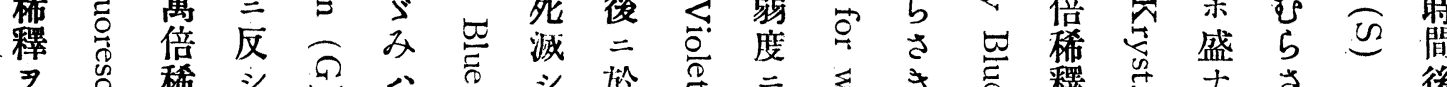

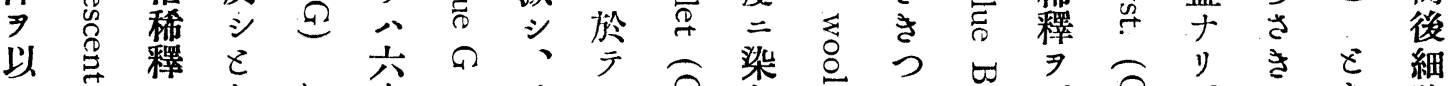

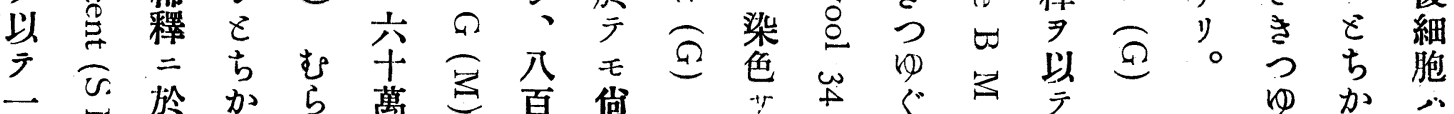

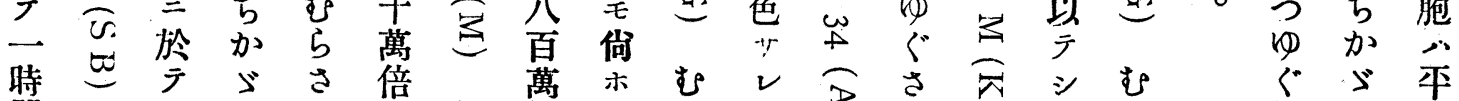

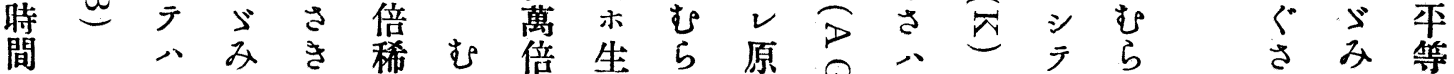

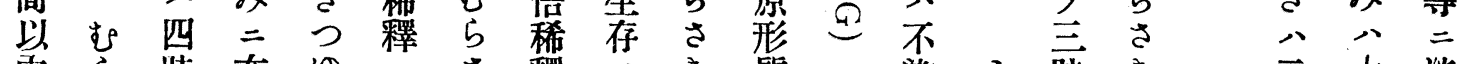

內 ら特在

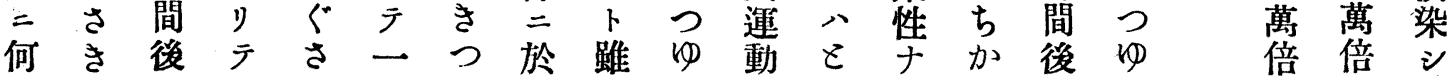

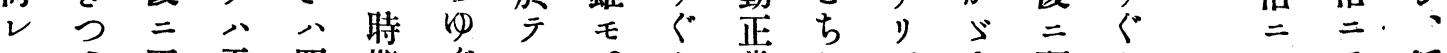

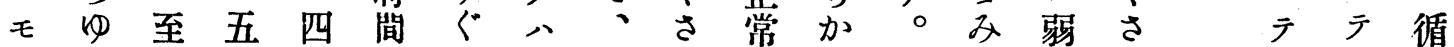

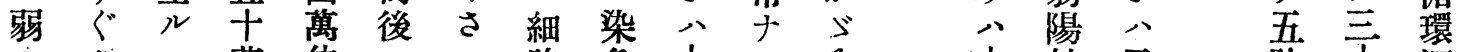

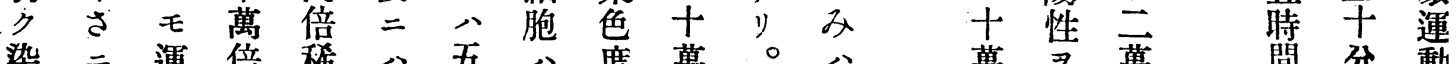

染二運倍稀吾吾度萬。萬萬間分動

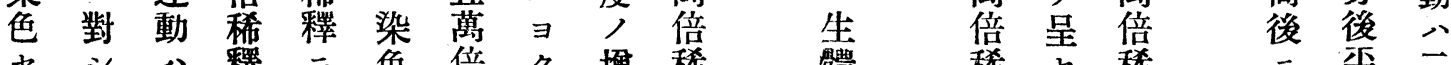

七 $、$ 䆁三色倍ク增稀體稀七稀三采三

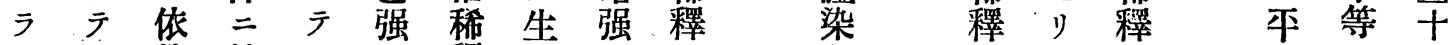

父然於二陽釋存 $刃=$ 色 $=0=$ 等 二 時

、声宁干性三不認示陰淡間

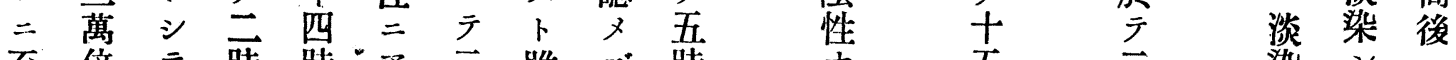

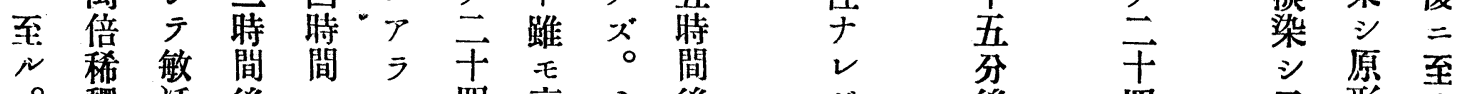

䆁 活 後二、、四毫 $\varepsilon$ 後

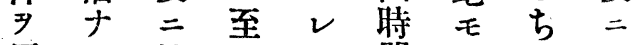

用 $v$ 於少原間染加於

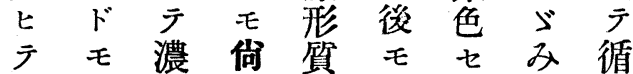

五染染源少循亏”環

時色染循趈環 2 於運

間 七色 環 轉 運 ズテ 勤

以

內ルラ動動 盛四ナ

二、レ活稍ナ面り

三然潑緩 2 萬掘

至力

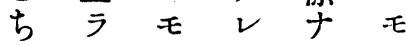

か ズ 原ドり全染

心笄飞。另於色

み臂毫染染度

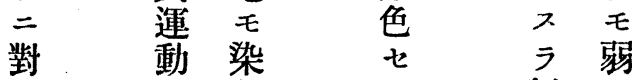

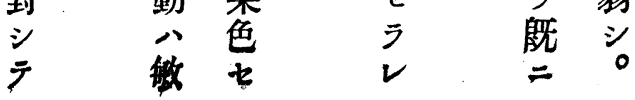

ド後

モ 中 时

、等間

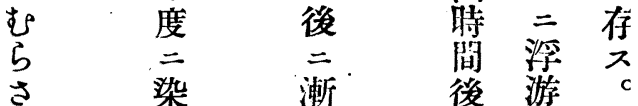

等

今

(1)

$<$

三 染强稍

萬每出

倍後 ラ ドス。

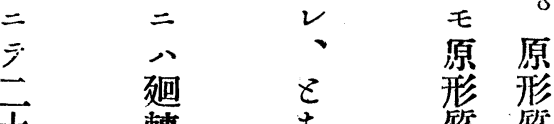

干 轉方質質

時動焉循 


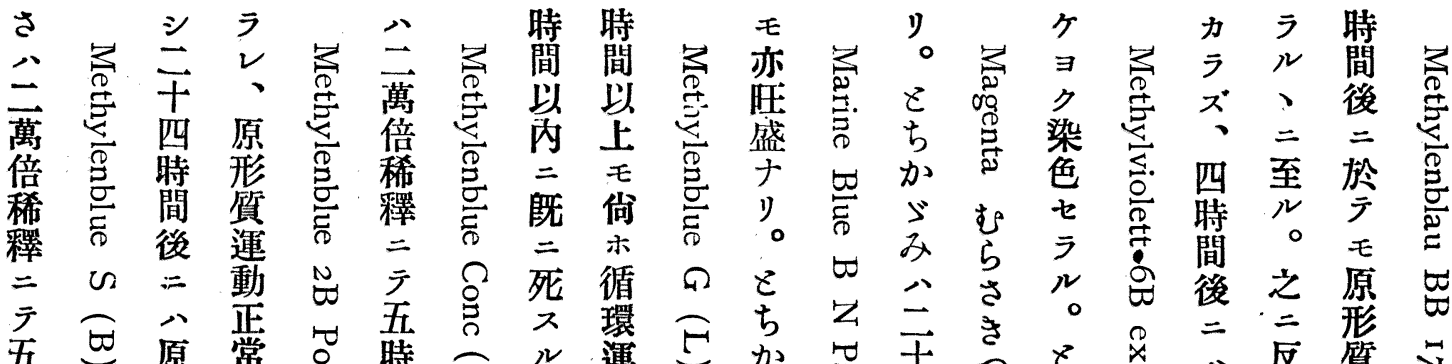

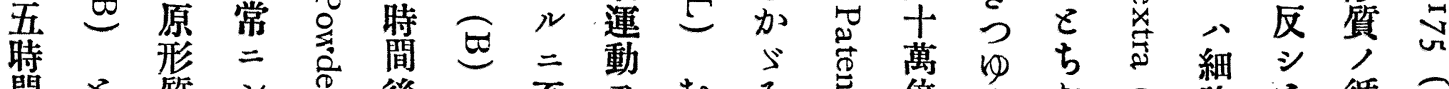

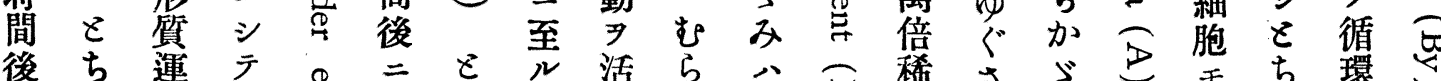

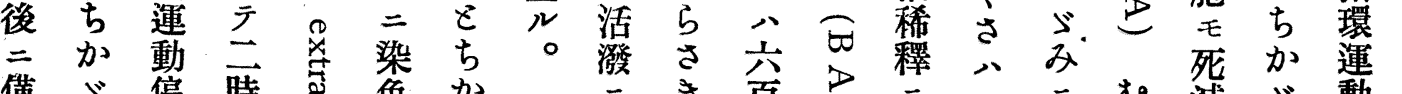

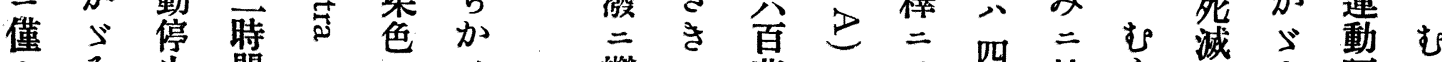

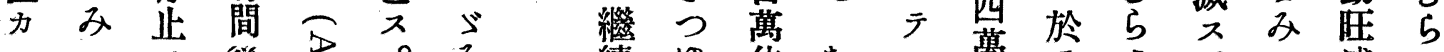

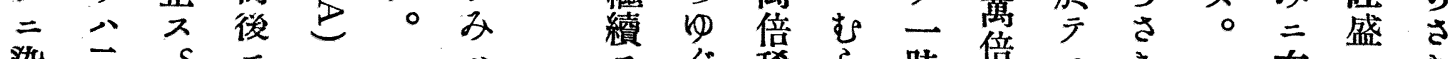

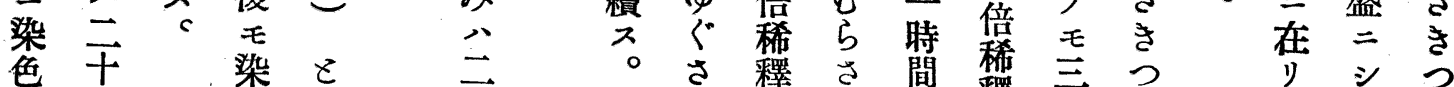

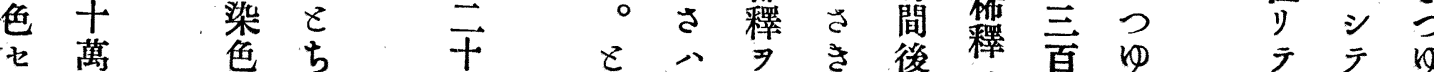

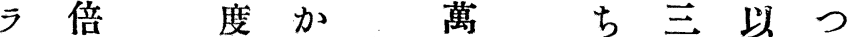
レ稀

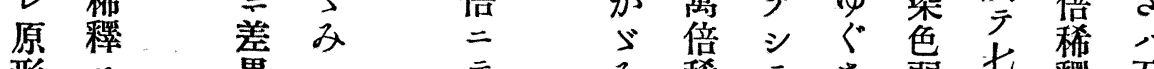

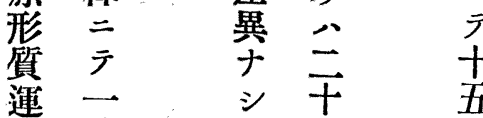

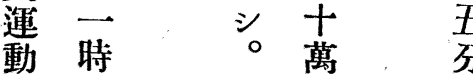
モ 間

大 後

む倍後

$=\quad \vec{j} \bar{j}$ 等

緩 淡

徐 染

只。原

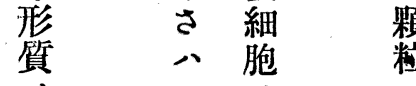

運萬原亦

動 倍 形

政: $\quad=$ 筫

ナ五平

》。㭙 等

後 菛

万 $\quad$ 等

さ本度

¿ 等

○ 染

虫梁色

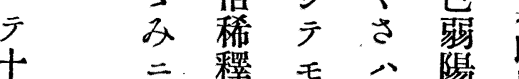

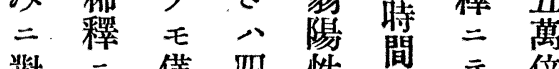

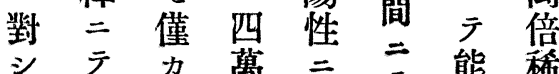

テ导二倍現テ能釋

、三二稀 只生染

干五犎釋儿體色 主

萬間後示毛急实京

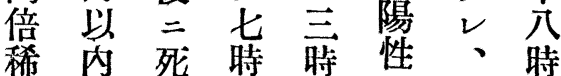

粒 $=$ 强 $シ$ 後 $シ$ 特後

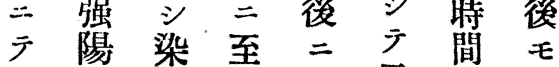

亦性色公京後倘

稍 時 二陰 心死十二木

間染性可隇四至盛

染

二色子十暲监

シ $九$ リ

$\overline{5}$ ○强二後趈形

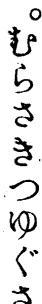

弱 V ク 至 $E$ 轉 質

》染循運

染然色。環董循

き色力七運邽環

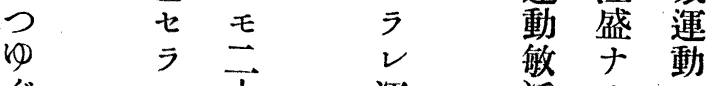

さ

四立

運

活り。續

八 染

百色 さ

萬度 二

倍毛 於

稀 增 广

釋 强, 八

於。洛

原 倍

言形 稀

侍 質 釋

間

後濃 テ

二禾

趈 等 間

轉二後

運 染二

動 色 弱

極七陽

又 亏 性

$\bar{v}=$

遲、染

細 色

ナ 胞七

》液

染 質

色牲

度淡 二

强七四 


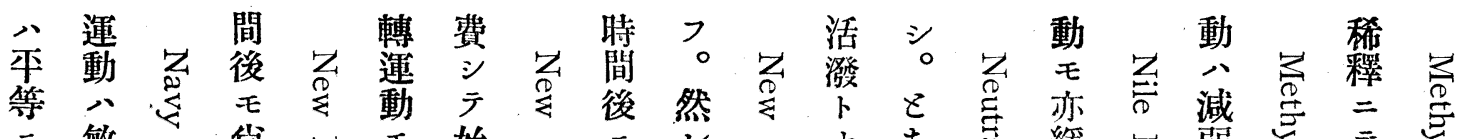
淡海

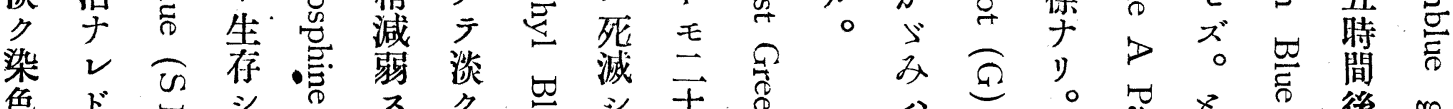

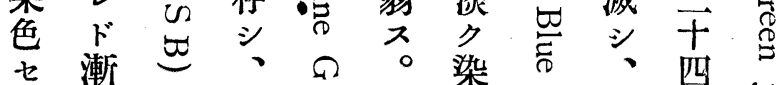
ラ次を色吼特无

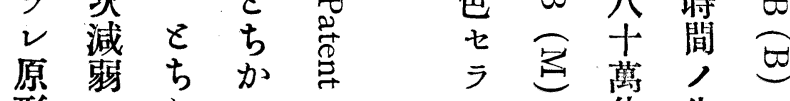

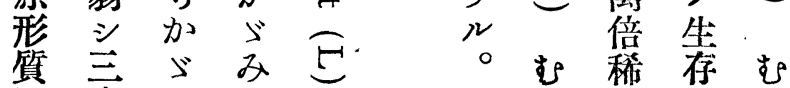

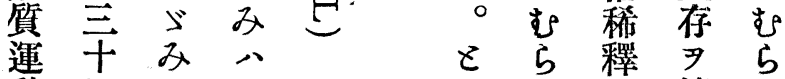

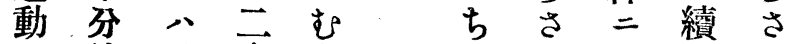
八後三干吉加き於宁き

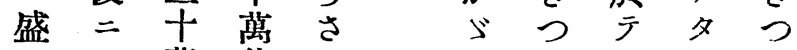
ナ八蕾倍きみゆモりりゆ 全倍 稀 つ

ドク稀 釋ゆ モ停釋 二 ぐ

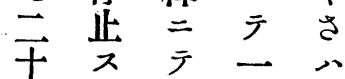
薮 ぐ ス 四ル十時三 時二五間葛 間至 分 以 五。 後少後內 干 二 。 原 二 倍 八む形 極 稀 死 5 質 邓 釋 滅劣 今 二 スき车淡 テ

ゆ 等”染 時

( 淡色 間

さ染 七 シ ラ テ 葛 特。體

倍 二 染

稀顆色

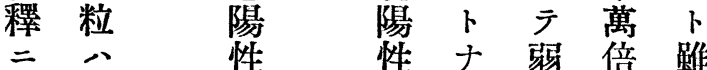

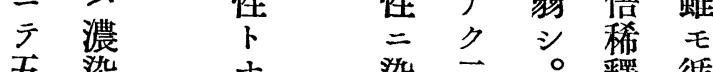

五染

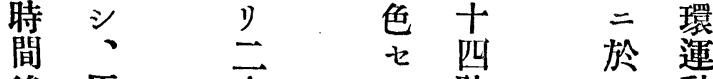

後 原古.

細形四

ラ 㭙

テ 動

胞 筫

時

\begin{tabular}{cc} 
简 & 閫 \\
\hline
\end{tabular}

モ 稍

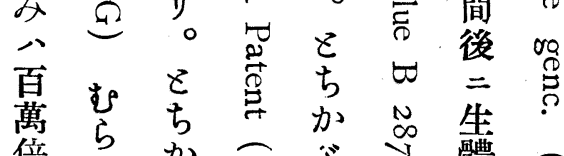

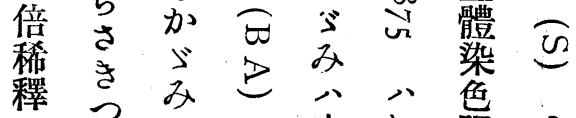

二ゆ

於尘、む萬ら性ち

テさ 三ら倍さ加

一市さ稀きり

時六萬き䆁つ。文

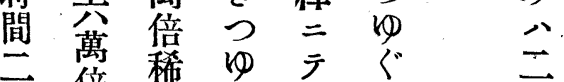

シ $\therefore$ 至

テ 萬苗古萬

二倍 分み 倍

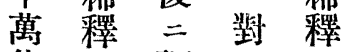

倍 = 趣 シ 二

釋五運 八於

於間㷲 毒 時

テ 後 海 間

時 八㢑ナシ

十色 染大染

五七色二色

=

テ、極四ル

三 倍 释

分䆁 こさ 時

テ

原於 時葛岗倍

形 八間 倍 二 稀

質二牛稀テ釋

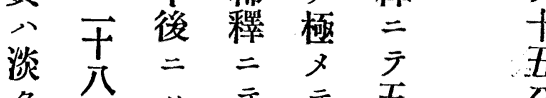

梁 特 原 八淡 時 分

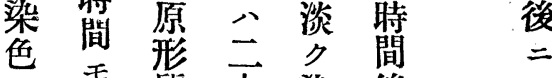

七生䫓干染 後

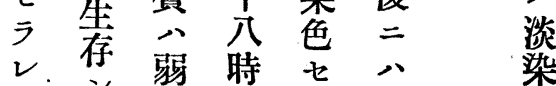

、错ク間 5 生

二 得 染二ル 體 ラ

時踓色厅。染

間 雖 七 弱

後壬 $三$ 陽罗主

二毫年性生方

、連采焉

原染動 成且き

形色モ 績 恶 う

質七活 $尹$ 原叫

趗ル 潑示 型

轉、少、

運 $=$ 循循

$\rightarrow$

動卜環環萬

不ナ連運

倍 


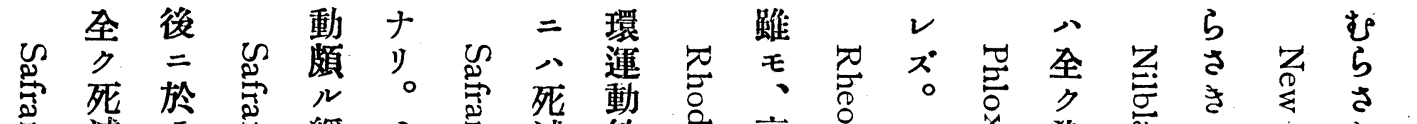

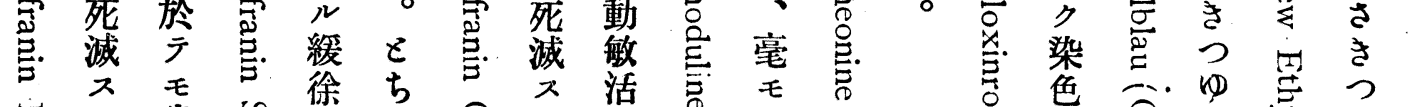

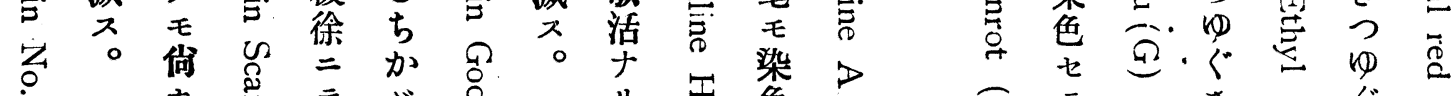

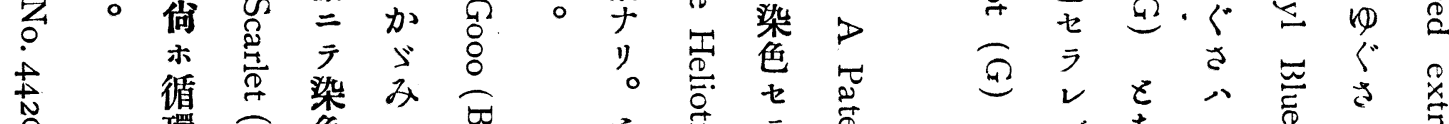

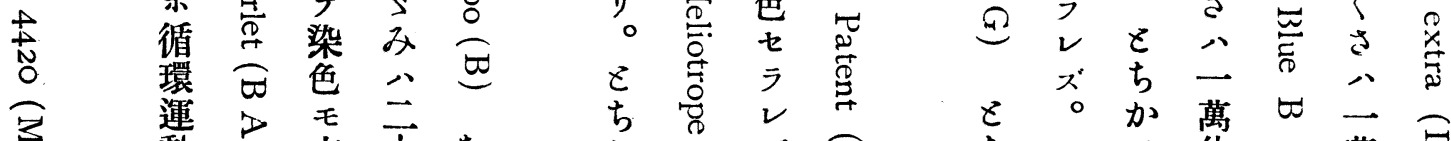

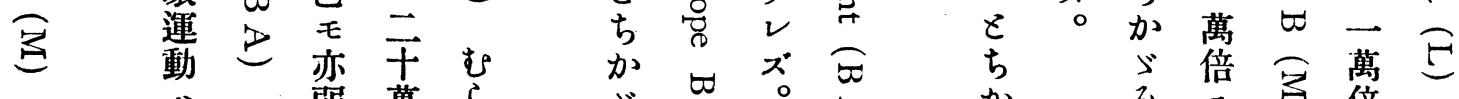

む活 む: 弱萬 ら

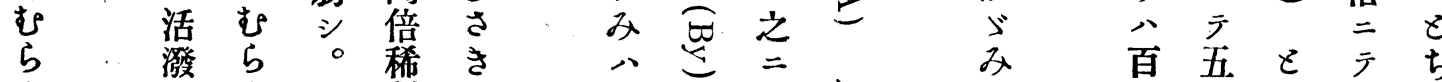

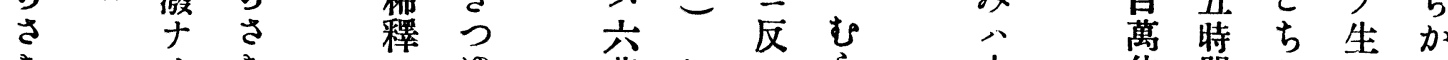

ききき

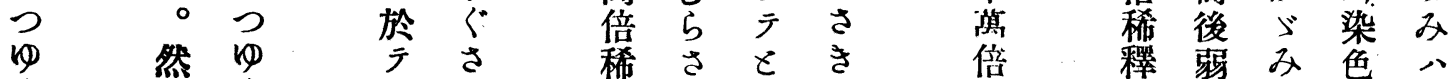

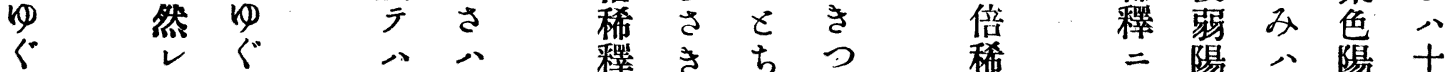

さ $匚$ a 一 六

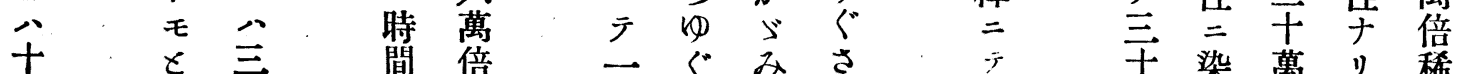

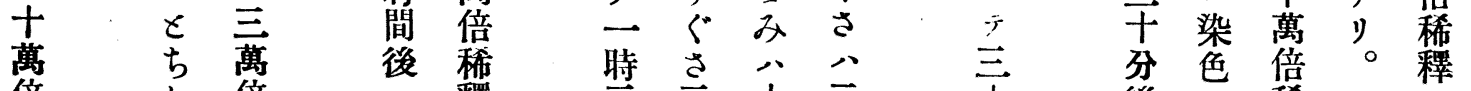

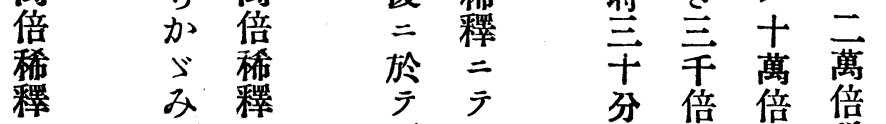

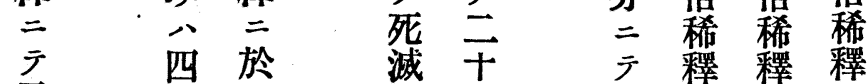

五十吾八弱

時萬五六時陽厅テテ於

間倍時十間

後稀 間 萬 循

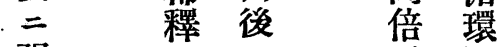

强 二 $=$ 稀連

采既釋釛

染 極二 活

色 邓 强於潑

七 テク テ

ラ 淡染毛行

只色 倘一

染七

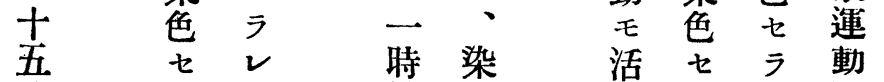

運 ク 染 循

性 六 $\overrightarrow{\text { 時 }}$ モ

染 䏺間 云

巴色間 後 古

亏 費 强 獎

文陽 間

名 宁 性 其

轉弱染循

木 $v$ 動染色環

特 ラ、間色

間 县年无

後 $\overrightarrow{\text { 時 }}$ 兰 後 中

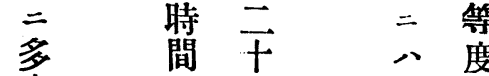

$\begin{array}{llll}\text { モ } & \text { 色 } & \text { 運 } \\ \text { 活 } & \text { ラ } & \text { 動 }\end{array}$

潑ラル堿

少後四 趈 =

ド原翟

原二時轉隄

四形來

形

運 性

蒔質节

後循

干 後

後原秷

二筫

生染

正

染弪

陵

性 


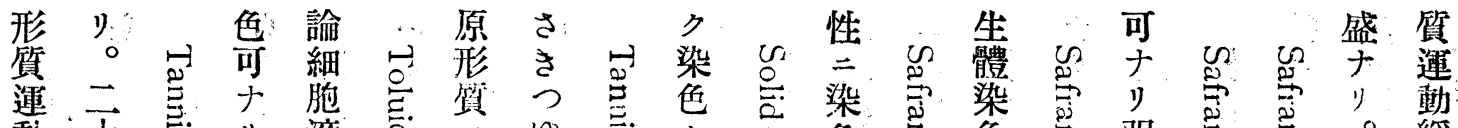
動 王

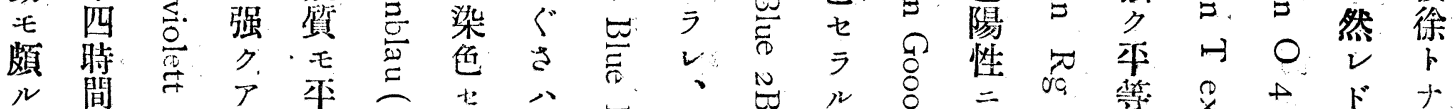

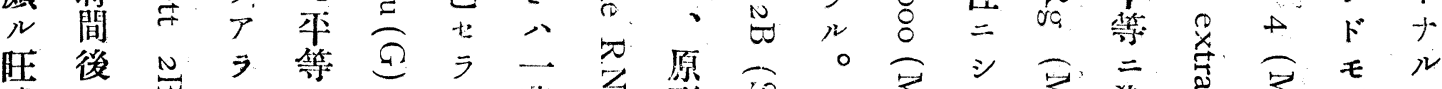

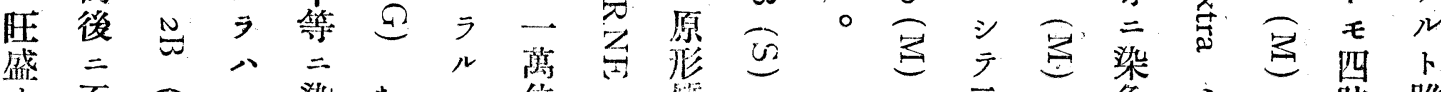

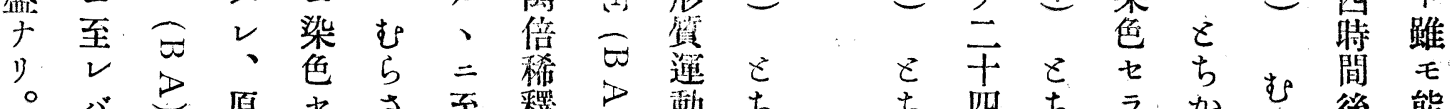

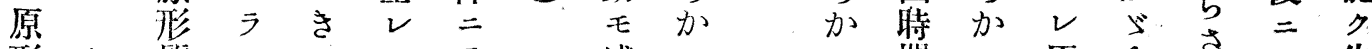

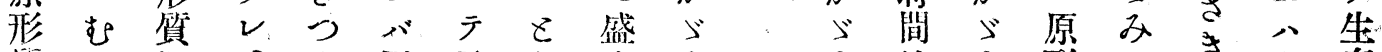

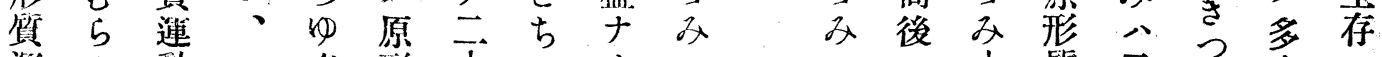

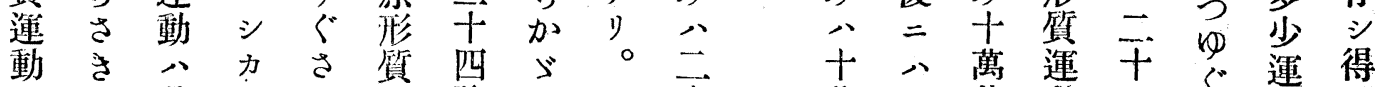

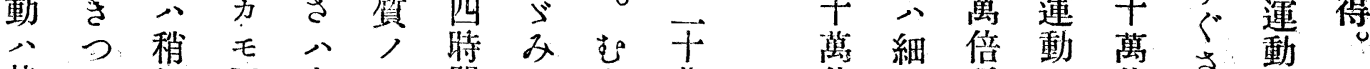

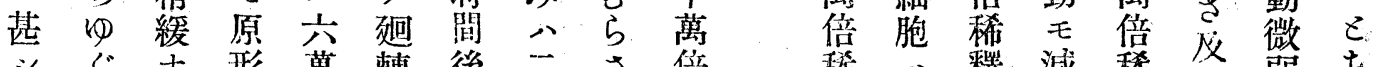

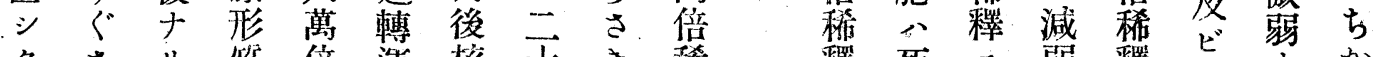

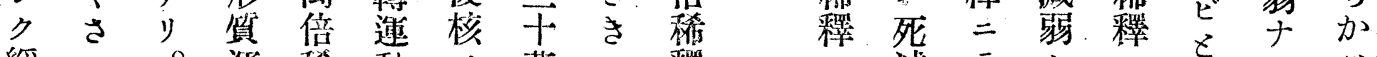

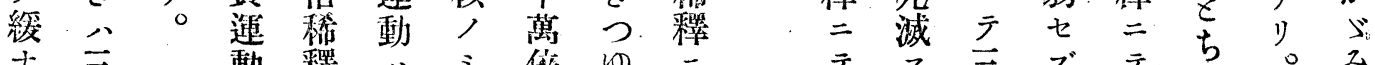
ナ三動 䆁 八ミ倍ゆ三

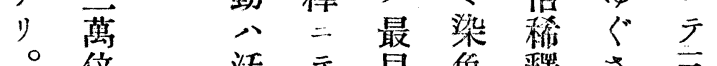
こ 倍 活 テ 早 色 䆁 さ ち釋 ナ特認原テ三分

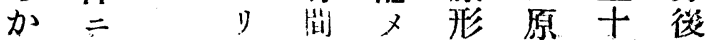
ア゙テ・染ラ貸形四原

み六を色

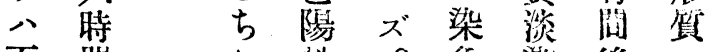

百間加。色媣後少

萬

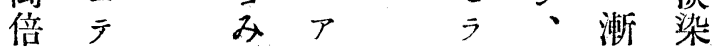

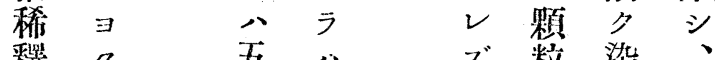

$\begin{array}{llll}\text { 釋 } & \text { 染 } & \text { 十 } & \text { ズ粒 染 } \\ \text { 染 }\end{array}$

色萬、原亦七学

一七倍二形可亏中

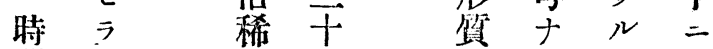

間 释四连少。包

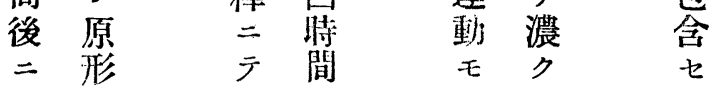

强翼 $\quad \overrightarrow{\text { 後 }}$ 正 染

染動 照二小常色

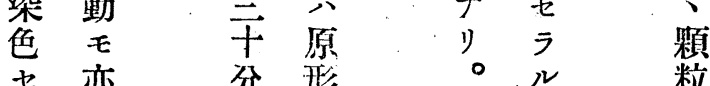

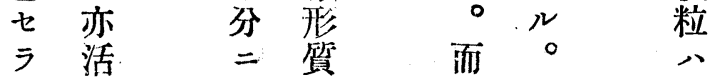

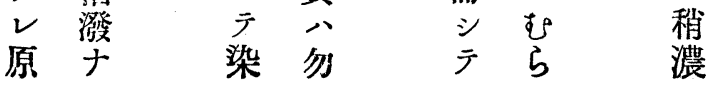

テ ス 主 ズ テ

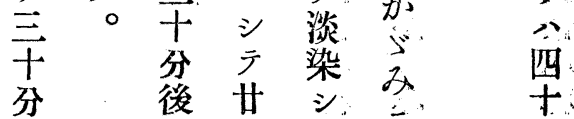

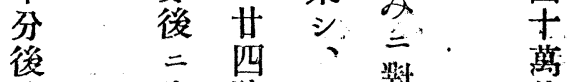

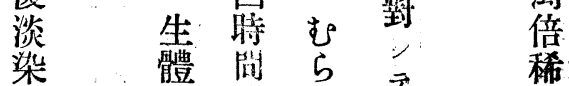

シ 染 後 さ 前 䆁

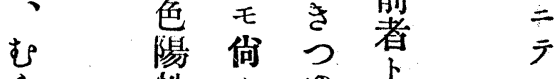

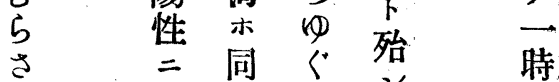

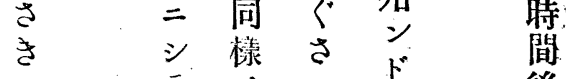

さ テ分 八 ト

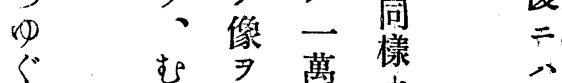

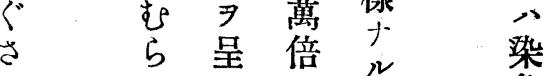

、

五: う j。主 績 淂

間留

後 く 間 得 县

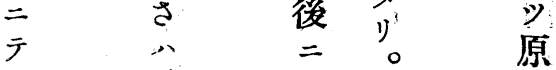

同五至等

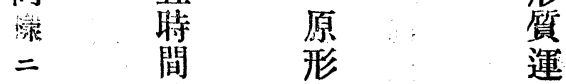

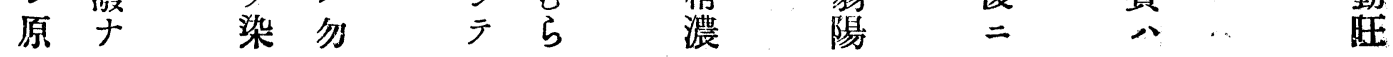




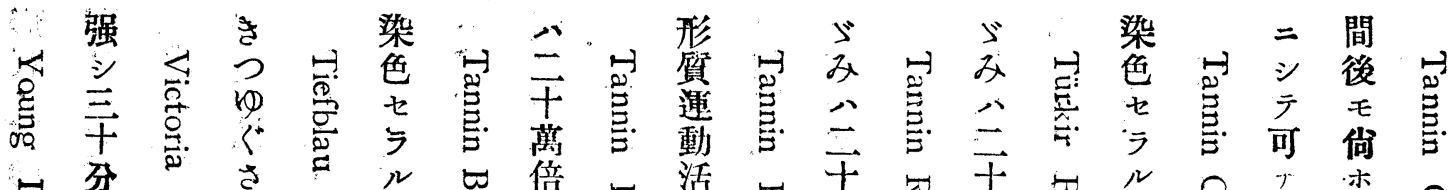

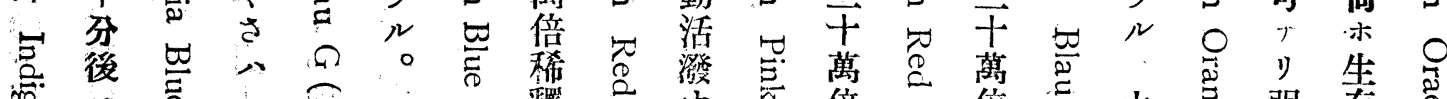

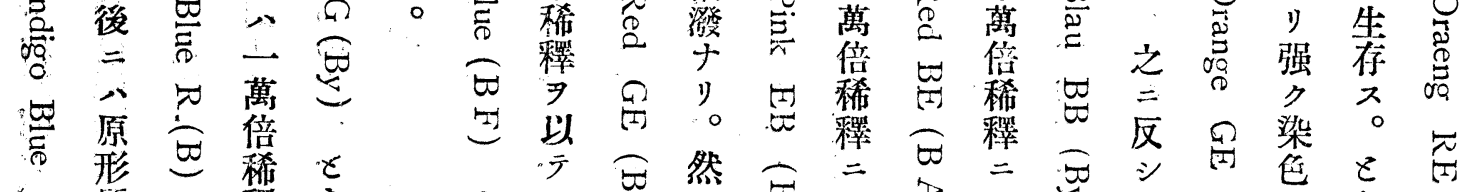

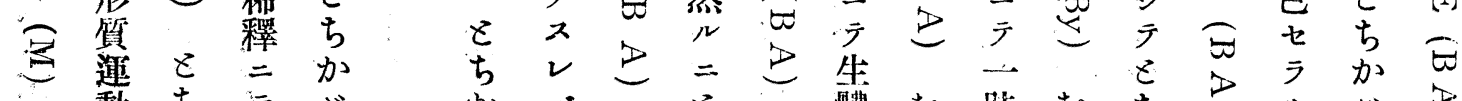

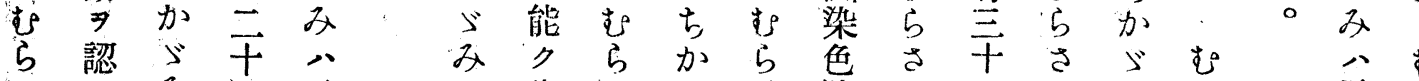

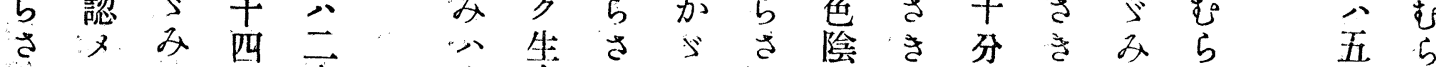

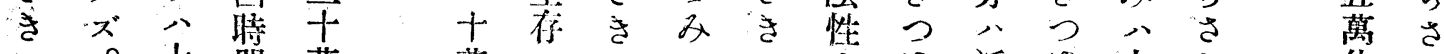

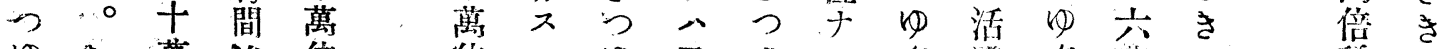

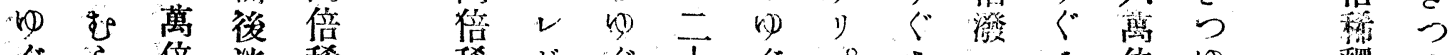

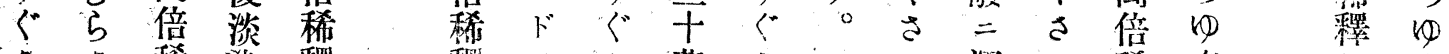
ささ稀 染 䆁 八き釋 七 六了五 萬ゆ倍分後。言

稀さ細分

糢 八胞・後 䆁もさ雚さ

八通 入椎ぐ

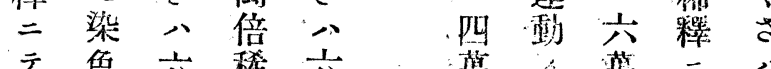

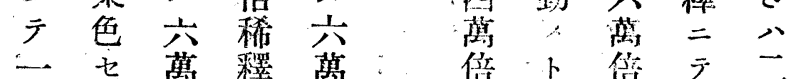

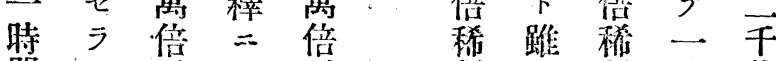

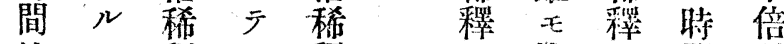

後、糬 一 釋

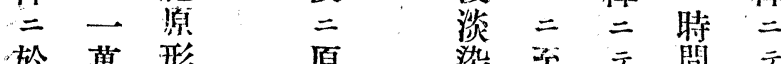

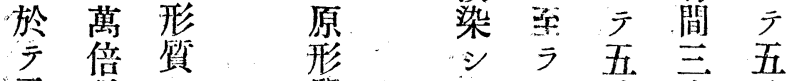

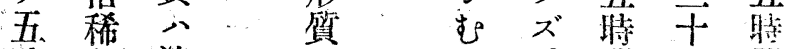

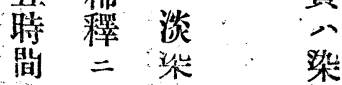

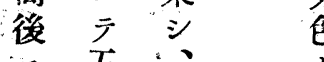

二五時顆: 七

可間 粒

于 後 $E$

y = 稍

强 方濃

ク 染 染

染色 ス。 通

七 $5+$ 稍

ラ 2 分 減

少。後弱

$\begin{array}{ll}\text { 而 } & \text { 染 } \\ \text { シ } & \text { 色 } \\ \text { 原 } & \text { 堵 }\end{array}$

$5 \circ$ 間 分 間

さ十以 後

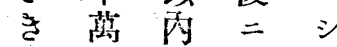

倍 二 モ テ

ゆ稀 强全强

ぐ䅸 ク ク 等

小二染染、染

原 三 只色色色

二染二間稀

テ色 テ 二糢

保七开不

木 能分 テ

F、少

$=<"$

於 d

厂

萭三它它

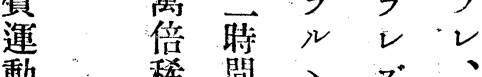

稀䦔 上

稺度度

弱无 死 $匚$ 四

ス 吾 死

ప
द

間

後

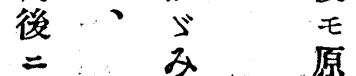

四: F 染 四

彇至四色 時

营

時罴

間 $\overline{\bar{F}}$

後 倍

二 稀

死 釋

減

シ テ

十

閏亏時七間售間

生 $x^{*}$ 間 $ラ$ 原稀 後

存。生 v 形釋二

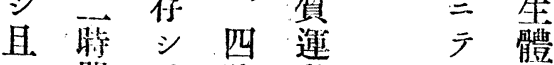

ッ間、倨動 八染

弱 後染間 $\exists$ 能色

ク 二色得活 品

染染蒻二潑 告性

色路陽 八二 存

七二性死繼 シ 示

亏死于 減、續

ル隇り。石弱

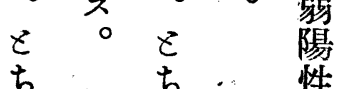

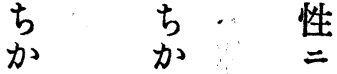

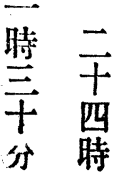




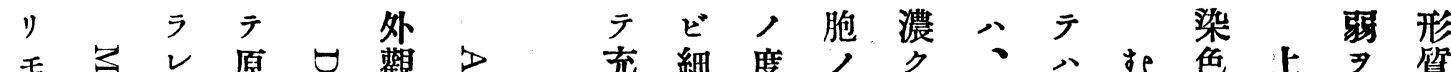

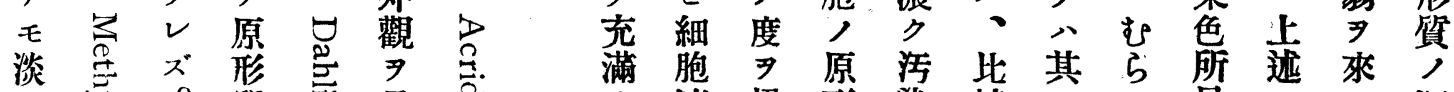

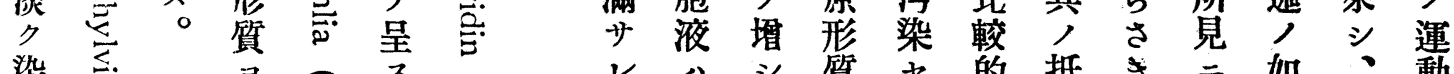

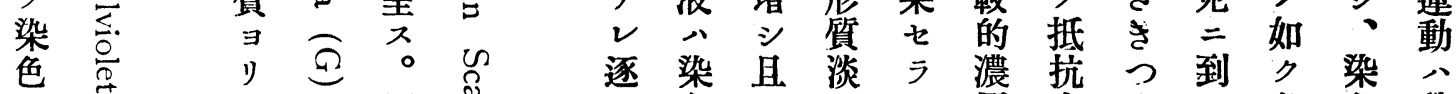
七色 ラ 濃む形市 八七其平、夜極ぐテ素弱減

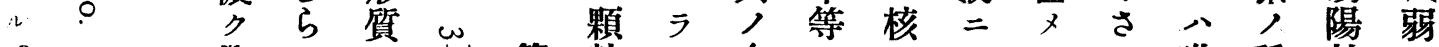

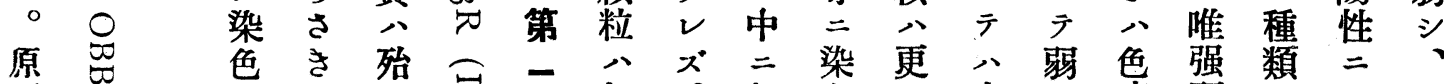

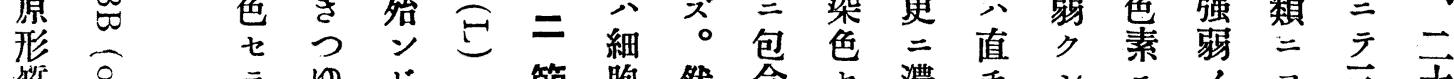

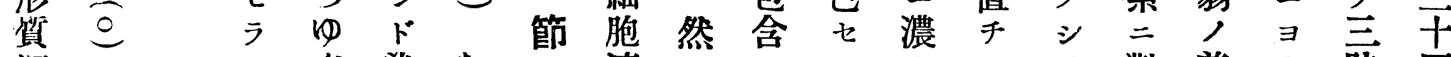

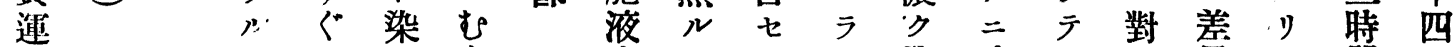

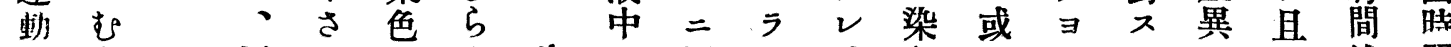
八ら原 稍さ形十ラき體流形、其七漸死抵ル供二後

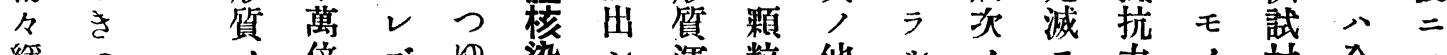
䌅つ少

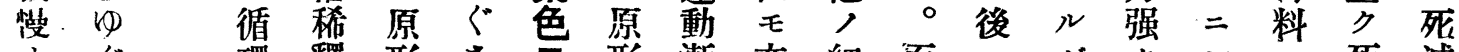
ナぐ環 釋 形さ三形漸亦細而二ガ少 シ 二死滅

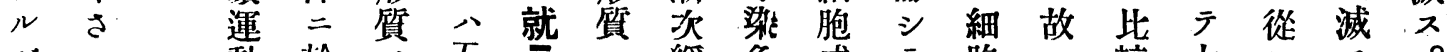

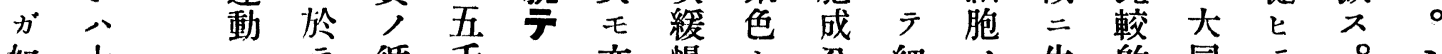
如十 $\therefore$ 循手 $\neq$ 萬 $\exists$ 五 環 倍 モ 倍只時連稀

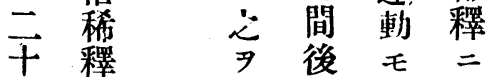

四二認二極 テ

時 テ公原 核

間五占形 テ 公

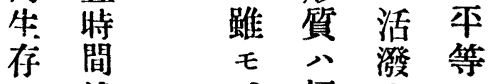
入 後、極十

二 可メり單

核 ナテ。調

染緩染淡溜

色 徐染性

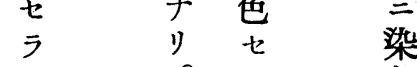

原細泉色

㣒、 胞、

質液占唯品

更全篗县

更全毛滑

核染核澤

亦慢七分細人生的同方 ${ }^{\circ}$

戀下ラ 八胞原體濃省染方 形ナ $v$ 毫液形染溶異色出 シリ遂モ質質色液ナ時留 テ遂三染モ連困二リ間。

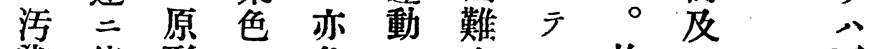
染停形七色八无故ビ 百 七止質 $三$ 素停り可二色惠 ラ ルンリズ以シ沓稀 、トモ、方、らナ方液釋 二ス濃 時 充 原ざ゙テ, 二 至儿染間滿形きク左濃江 几 頃七人質了生主度立 三 ラ 經。公以存訅等”。時 至ル過生破ぐ汐述種間 レ、三體壞さ得 ス名牛

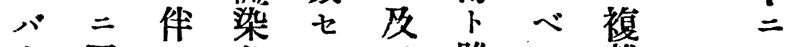

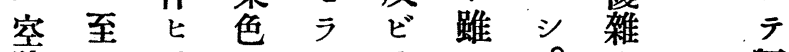

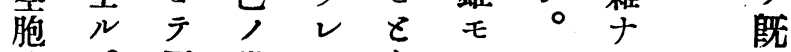
内。原當テちちを. ル モ而形初收吕ち關原

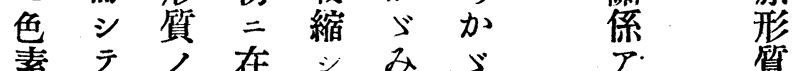
溶 細 染 在ジみみみ 液胞色 テ平在三兟 $\exists$ 却知 以策其 細 


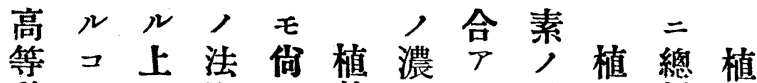
動 卜三則木物度り性物括物 物必大 3 生細 $尹$ 。質細的細 細要 求體胞檢其 $\exists$ 胞二胞 胞ナル染染索レり八退人, 二り關ル色生ス故考色ブ生 生。係コ榎體ルニフ素ル體 體故 $刃$ 性染コ植 $ン=$ 所染 染三有能ナ色卜物心對厂色 色植ス八ル晹最細當スラ機 榎物 $ロ$ モ 性 モ 胞然ルンン轉 性人概。万十必了生抵卜元 ナ生シ之尠ル要生體抗 ス色 ル體テニシ色ナ體染力。素 色染云反卜素り染色極 素色へシ七八。色陽

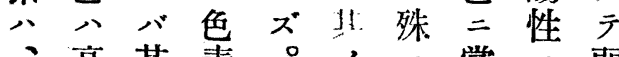
高其素。广二當三弱

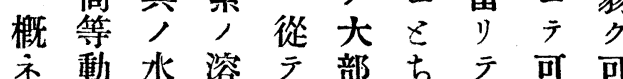
衤動 水溶 穴部 物了夜中體、父、ルリ 細生ガ二染籚み個べ稀 胞體真於色基二々キ. 溥 人染性竹性於, モ于 生色溶ル性二テ色ノル 體大液色ノ素モテ然素二色 染大ナ素モモテり。溶 モ素 陰其力摭卡强掏液 性了或散陰姴就當二 二趣 八相性性 シキ之特, 尹 テ $尹=$ 示 高異近色, ス 等 動 三性粒, 閏 物 、牀子間 多 細、郎人立辛。 素—キ 超人定少ルレ 生性度 一化 ド 體牀人生學モ 染曞體構 酸 色り散染造性 陽觀性色式色 性江 7 二素 声有生定
厂, テ

供 濃 モ

䛋度其

材,, 二

料色危章

素害 二

龉 量 $\exists$ 述

ス 眥命

儿混公

毒入

性 ス

$\exists ハ$ 上

顧 コ大

慮トナ

柁 リ

以八。基

テザ 故 キ

適 ル二

當場色

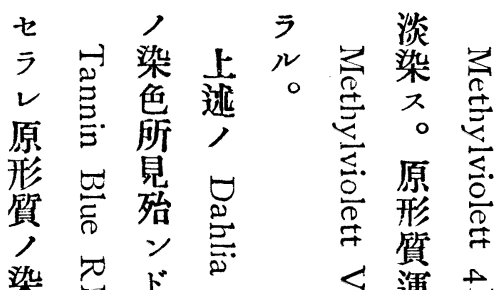

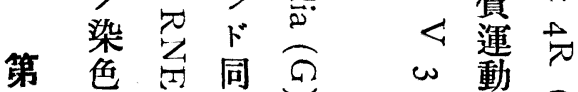

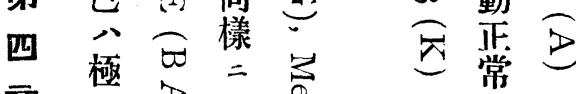

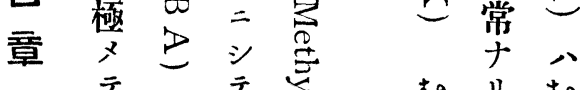

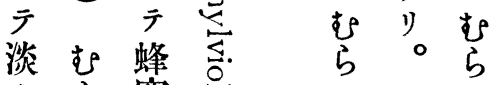

及植クら窩离さささ

㫐物、ささ樣き き き

理細細原き父公つ

华兽胞形つ八ゆゆ

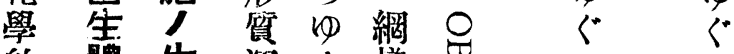

的體生運ぐ樣芯ささ

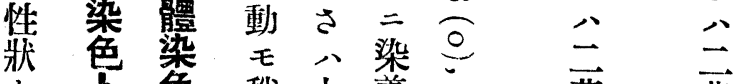

卜下色稍六着落萬

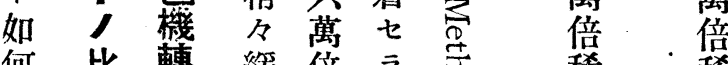

何比轉緩倍亏导稀・稀

ル色り䆁レ过䆁 䆁

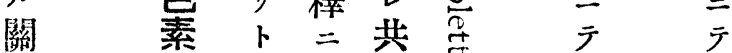

係与踓厅核今五五

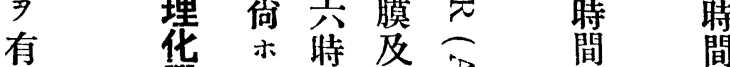

舅三間 ビ巳 後後

的卉後核㝒 二

性八三悉原核

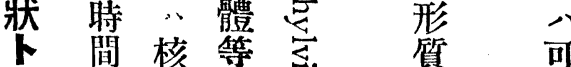

生 八 $、$ 只

關存平著㪳平紧

係 等 明く等濃

前 ${ }^{\circ}={ }^{\omega}$ 可濃

動 于染

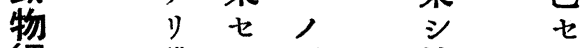

細濃 ラ四核 ラ

胞每ル色恙稍

㬨、素 稍

性至於多形

二ラテ 染質

染䓃。核色毛亦 
卜陽 溶 度二 A心NE本本陰性液 $尹$ 對植

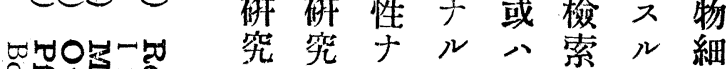

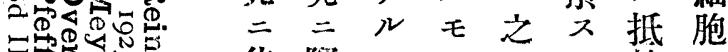

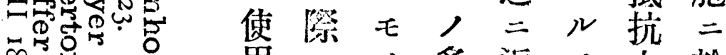
角落, 多近, 方於 七終卜クキ必極

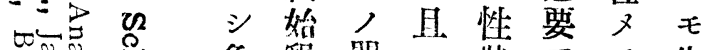

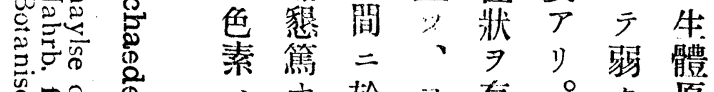

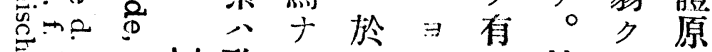

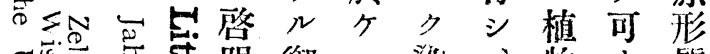
志总总总明御\%梁、物大質

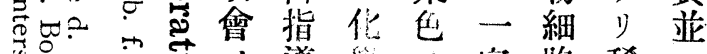

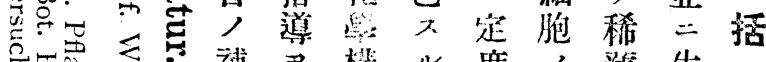

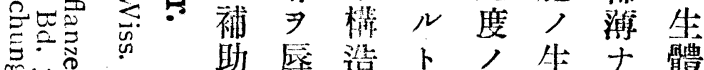
助辱造卜等

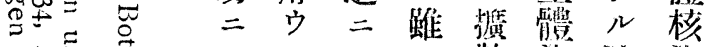

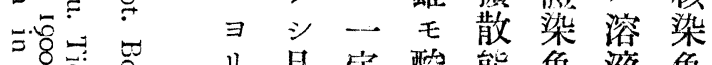

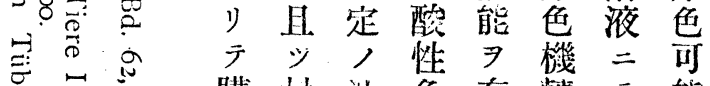

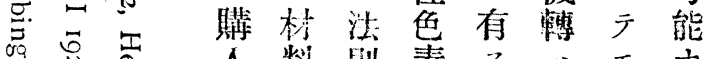
品过惫 人料則素入父モナ 七 $尹$ 瓜色容り 今惠定於 $\Rightarrow$ 素易。

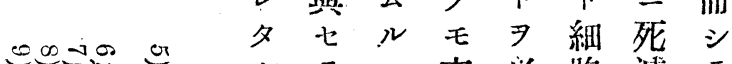

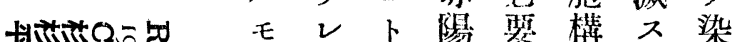

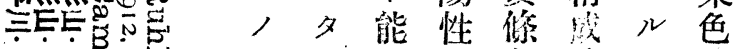

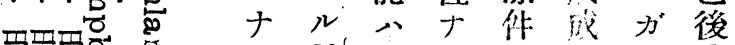

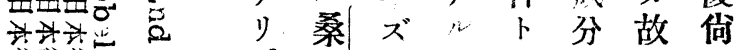

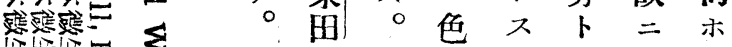

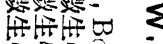
舟敉

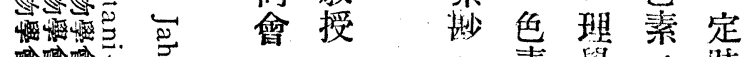

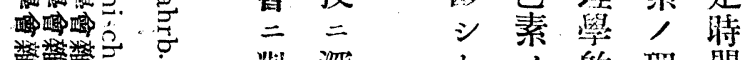

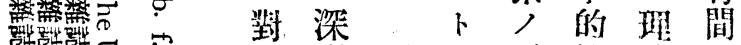

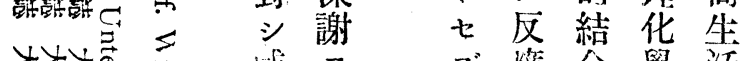

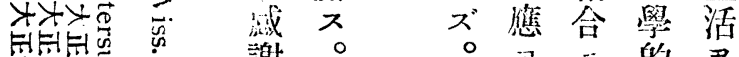
†1! til

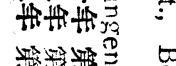

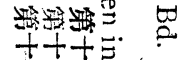

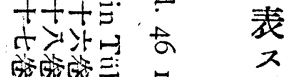

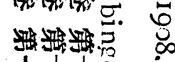

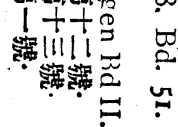

諸卜色酷ノ有 シ モ 細色斯素植似生入酸, 胞梁り 二粒ノ種細卜染。色、 現子如類治踓色然素植 八人 ル荷動後生、生ド凡、細 、雷物沓體斯 ジモテ胞 生状細 $\Rightarrow$ 染得植超人 檄物態胞生色, 心゙物生生 學及二ズ、如キ細體體

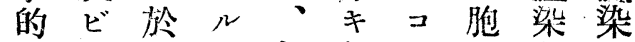
現色厅色細劃卜二色色

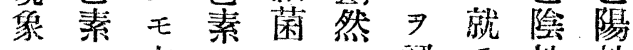
卜人亦, 万㤎認姓性 シ撗植柾生ルム八ナノ

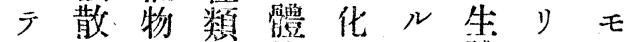
相能細当染學二體。” 似ガ胞り色棈至染故多

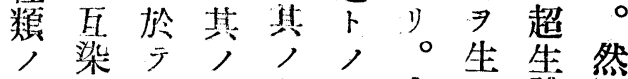

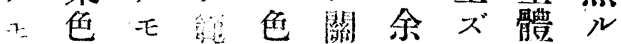
，卜色圆素係等 ル染二 十.密素大ノ

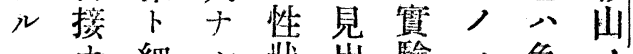
コナ細ル状出騟, 、色, トル胞, ヨス二殆素研

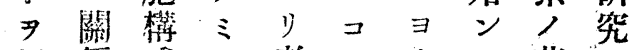
想係成广葆卜リド荷”

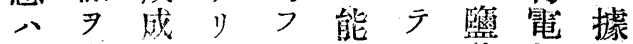

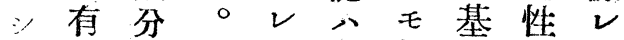
么 ス卜 バ ズ其性從バ ○ル人进。广色厅超 工結，名機素其生 卜合”相轉于分體 八刀 似 = 劣化染 是常名於卜學色 等三ル示七的陽 睍理モ心ラ構性 像學, 動レ造ナ

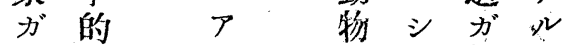

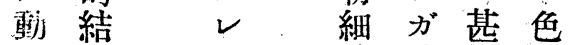
植合师酸夕素 物二陮, 性密公 界湔超色接凡 $\Rightarrow \quad$ 者 牛素 $テ$

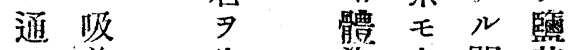
渚 生 染亦關基 テ現六色植係二

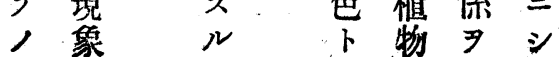

